\title{
GÜVENDE: Çocuğu Kötü Muamelenin Etkilerinden Korumak İçin Neler Yapılabilir?
}

\section{SAFE: What Can Be Done to Protect Children From Effects of Maltreatment?}

\author{
Ahu ÖZTÜRK ${ }^{1 *}$, Muhammet Cevher TAT ${ }^{2}$ \\ ${ }^{1}$ Öğretim Üyesi Doktor, Bursa Uludağ Üniversitesi, Fen-Edebiyat Fakültesi, Psikoloji Bölümü, \\ ozturka@uludag.edu.tr, orcid.org/0000-0003-0349-7342_Sorumlu Yazar \\ ${ }^{2}$ Psikolog, Öncü Okulları, cevhertat@gmail.com, orcid.org/0000-0002-9837-710X
}

Geliş tarihi/Received : 14.07.2021 Kabul tarihi/Accepted: 20.12.2021 Yayın tarihi/Published: 30.12 .2021

\begin{abstract}
ÖZET
Bu çalışma, çocuğa kötü muameleye dair güncel alan yazından derlenen bulgulardan yola çıkarak etkin önleme ve müdahale hizmetlerinin kapsaması gereken unsurları açıklamayı hedeflemektedir. GÜVENDE olarak adlandırılan bir çerçevede sunulan bu derleme çalışmasının temel hedefi, çocuğa adli, sosyal ve psikolojik destek hizmetleri yürütenleri çocuğa kötü muamelenin önlenmesi ve müdahalesi hakkında bilgilendirmektir. Dört temel unsur içeren GÜVENDE'de ilk olarak kötü muameleyi önlemenin temel yolu tanıtılmaktadır. Son üç unsur ise kötü muamele gören çocuğa etkin müdahalenin niteliklerini tanıtmaya ayrılmıştır. Çocuğa kötü muameleyi oluşturan etkenlere ve onun oluşturduğu çok düzeyli etkilere dair kapsamlı bir bakış açısının benimsenmesinin, koruma ve destek hizmetinin niteliğini ve ürettikleri yararı artırma potansiyeli yüksektir. Kötü muameleye uğrayan çocuğa kamusal destek hizmeti verenlerin nitelikli müdahalesini destekleme amacını güden kapsayıcı ve sistematik bilgi sunma çabalarının, sadece destek hizmeti sağlayıcılarını değil toplumun da çocuğa yapılan kötü muameleyi durdurma potansiyelini artıracağı düşünülmektedir.

Anahtar kelimeler: Çocuğa kötü muamele, çocuk istismarı, çocuk ihmali, müdahale, çocuk koruma ve destek hizmetleri

ABSTRACT

This study aims to explain the essential elements of effective prevention and intervention services based on the findings compiled from the current literature on child maltreatment programs. This review, presented within the SAFE framework, mainly aims at security forces, social workers, and counselors who give psychological or forensic support services. Among a total of four, the first step of SAFE is about the main path of preventing maltreatment. The remaining three steps are devoted to introducing the qualities for intervention with maltreated children. Adopting a comprehensive approach covering factors that constitute child maltreatment and its multi-level effects has a high potential to increase the quality of the protection and support service and the benefits they produce. We believe that efforts to provide a comprehensive and systematic literature review that aim to support qualified public support service for maltreated children will improve service providers' and society's potential to stop child maltreatment.
\end{abstract}

Key words: Child maltreatment, child abuse, child neglect, intervention, child protection and support services 


\section{GİRIŞ}

Her çocuk, yaşamını sağlıklı bir gelişimsel seyrinde sürdürmeyi hak eder. Toplum olarak bizler, çocuğun yaşadığı çevresel koşullar değişse de sağlıklı gelişme ve yaşama hakkının, en yakınlarındaki yetişkinler tarafından güvence altına alınmasını bekleriz. Fakat bazı durumlarda bu haklı beklentilerimizin aksine, en yakınındakiler çocuğa en çok zararı verir. Çocuğa kötü muamele, bir yetişkin tarafından çocuğa uygulanan her türden kötü davranış olarak tanımlanmaktadır. Her türden kötü muamele, tek defalık veya tekrarlayıcı olmasından bağımsız biçimde, önemli bir hak ihlalidir ve çocuğun sağlığına, gelişimine ve onuruna doğrudan zarar verir (D'Andrea, Ford, Stolbach, Spinazzola ve Van der Kolk., 2012). Çocuğun kötü muamele içeren istismar ve ihmal davranışlarına maruz kalması başlı başına gelişimsel bir risk olarak ele alınmaktadır (Dünya Sağlık Örgütü [WHO], 2002). Çocuğa karşı işlenen suçları yirmi seneyi aşkın süredir araştıran Finkelhor, Wolak ve Berliner (2001), bir veya daha fazla yetişkinin çocuğu mağdur ettiği ve çocuğa zarar verdiği her türden edimin suç olarak nitelendirilmesi gereğini vurgular. Tüm bu nedenlerden dolayıdır ki, ülkemizde de istismar ve ihmal çocuğa karşı işlenen en temel suçlardan biri olarak kabul edilir ve çocukların korunması veya yasal konular kapsamında ele alınır (T.C. Kalkınma Bakanlığı Onuncu Kalkınma Planı Çocuk Çalışma Grubu Raporu, 2014).

Kötü muamele; fiziksel, cinsel ve duygusal istismarı veya ticari veya diğer türde kötü niyetle faydalanmayı ve ihmali kapsar. Kötü muamelenin iki temel yönü olan istismar ve ihmali birbirinden ayıran kilit nokta ise; çocukluk döneminde en çok ele alınan kötü muamele türü olan istismarın aktif ve ihmalin ise pasif doğasıdır (Öztürk, 2020). Bir kişiye yönelik ve aktif zarar verici eylemleri istismar tanımlar. Farklı türlerde istismar olmakla birlikte, fiziksel ve cinsel istismarın çocuğa karşı işlenen suçlar arasında yüksek oranlarda gözlendiği saptanmaktadır (Türkiye İstatistik Kurumu [TÜIK], 2020). Çocukluk döneminde en somut delili ile gözlenen kötü muamele türü fiziksel istismarıdır. Çocuğa fiziksel istismar davranışları, fiziksel olarak zarar oluşturan ya da oluşturma potansiyeli olan; "çocuğu omzundan tutarak sarsmak" veya "yakıcı bir alet ile vücut bütünlüğüne zarar vermek" gibi farklı kapsamlarda ve çeşittedir (Maguire-Jack, Gromoske ve Berger, 2012). Çocuğa cinsel istismar ise bir bakım veren veya bir yetişkin tarafından çocuğa yöneltilen ve haz alma niyetiyle elle tacizden fiili livataya uzanan her türlü cinsel aktiviteler olarak tanımlanır. Günümüzde bahsedebileceğimiz istismar yöntemlerinden bir tanesi internet üzerinden gerçekleşen "çevrimiçi çocuk istismarı"dır. Temas içermeyen cinsel istismarın kayıt altına alınarak çocukların teşhir edilmesi, siber zorbalığın ve cinsel dokunmayla gerçekleșen cinsel istismarın önünü açmaktadır (Çalışkan, 2019). Tüm diğer istismar türlerine eşlik eden bir kötü muamele türü ise duygusal istismardır. Duygusal istismarcı çocuğun hareketlerini sınırlar, küçümser, çocuğa iftira atar, istismarın suçunu üzerine atar, çocuğu tehdit eder, korkutur, çocuk ile diğerleri ile arasında fark gözetir, alay eder veya diğer her türden fiziksel olmayan düşmanca ve reddedici sosyo-duygusal davranışlar ile çocuğu istismar eder. Çocuğa kötü muamelenin ikinci temel türü olan ihmal, kötülügün pasif yönüdür. İhmalkâr bir çevre; çocuğa sağlik, eğitim, duygusal gelişim, beslenme, barınma ve güvenli bir ortam sağlama konularında yeterli ilgiyi veremez (Öztürk, 2020). Toplumun çocuğu korumaması/koruyamaması veya sorumluluğundaki çocuğun durumunu takip etmemesi çocuk ihmali kapsamında değerlendirilmektedir (WHO, 2002). Çocuğa kötü muameleyi konu edinen adli vakalar ele alındığında, şikâyetlerin ekseriyatla istismarın nadiren ise ihmalin olduğu görülmektedir (Development Analytics. 2017: TÜIK. 2020). 
Çocuğa kötü muamelenin art alanı, çoklu çevresel risk etkenlerini barındırmaktadır (Cicchetti, Toth ve Maughan, 2000; MacKenzie, Kotch ve Lee, 2011). Çocuğa kötü muameleyi anlamak için, birden çok sistemin etkileşimi açısından ele almak ve kapsamlı bir yaklaşım izlemek şarttır (Belksy, 1980). Çocuğa kötü muamele Belsky'nin Ekolojik Yaklaşım ile ele alındığında; birey (ontojenik gelişim), aile (mikrosistem), topluluk (dış sistem) ve kültür (makro sistem) düzeylerinde iş başında olan güçler tarafindan belirlenen bir sosyal-psikolojik fenomen olarak kavramsallaştırılır. Bu kavramsallaştırma, kötü muameleyi bireye veya aileye özel bir sorun veya olgu olmaktan çıkarır ve daha uzakmış gibi görünen dış sistem ve makro sistemleri kötü muameleye doğrudan dâhil olan unsurlar olarak belirtir. Bir toplum çocuğa kötü muamelenin olumsuz gelişimsel etkilerini önleme ve en alt düzeye indirme hedefine, ancak sağlık ve sosyal destek alanında hizmet veren meslek elemanlarının kötü muamelenin özelliklerine dair kapsayıcı bilgisi olduğu sürece ulaşılabilmektedir (Birleşmiş Milletler Çocuklara Yardım Fonu [UNICEF], 2012; Lee ve Chou, 2016). Bu derleme çalışmasının amacı, destek hizmeti sağlayıcılarının çocuk istismarı ve ihmali vakalarını azaltmaya yönelik çabalarına katkı sunmak amacıyla; çocuğa kötü muamelenin önlenmesi ve müdahalede farklı düzeylerdeki ekolojilerin kolaylaştırıcı ve zorlaştırıc1 etkilerini tanıtan GÜVENDE isimli bir rehber sunmaktır.

\section{YÖNTEM}

Kötü muamele karşısında çocuğa nitelikli destek hizmetinde gözetilmesi önemsenen kilit unsurlara dair bulguları ayrıntılı ve sistemli biçimde tanıtan bir kaynak niteliğindeki bu çalışmada; çocuğa kötü muameleyi önleme ve müdahale konulu uluslar arası ve ulusal alanyazın Google Akademik, ScienceDirect ve Ulakbim Tr Dizin veri tabanları Türkçe ve İngilizce dilleri için taranarak derlenmiştir. Son kırk senelik (1980-2020 yılları arası) dönem için yürütülen sistematik taramada; 1) kötü muamele ("kötü muamele", "istismar", "ihmal") ve çocukluğa ("bebek", "çocuk", "ergen"), 2) psikolojik destek hizmeti ("psikolojik destek", "önleme”, "müdahale") anahtar kelimelerinden yararlanılmış ve eser türü "araştırma makalesi", "sistematik derleme" ve "meta-analiz" olarak belirlenmiştir. Bu seçim ölçütleri ışığında, çoğunluğunu görgül araştırma ve kitap bölümlerinden oluşan toplam 84 eser derlenmiştir. Ulaşılan araştırma raporlarının \%11'inin ise kaynağının resmi kurum, vakıf ve kuruluşlar olduğu belirlenmiştir.

$\mathrm{Bu}$ kaynaklardan, kötü muameleden çocuğu korumanın kontrollü ve nitel araştırmalar ile incelendiği 23 çalışma olduğu tespit edilmiştir. Bu sistematik derlemede ayrıntıları ile ele alınan kötü muamele konulu 23 çalışmanın derlemede yer verildiği koruyucu temel unsura, araştırma desenine ve tartı̧̧ma odağına dair bilgiler Tablo 1'de sunulmuştur. 
Tablo 1. Çocuğa Kötü Muamelenin Olumsuz Etkilerinden Koruyucu Unsurları Konu Edinen Makaleler*

\begin{tabular}{|c|c|c|c|}
\hline Kaynak** & $\begin{array}{l}\text { Koruyucu } \\
\text { temel unsur }\end{array}$ & Araştırma deseni & Tartışma \\
\hline $\begin{array}{l}\text { Akyol ve } \\
\text { Kutlu, } 2019\end{array}$ & $\begin{array}{l}\text { Eğitim- } \\
\text { Bilgilenmek } \\
\text { (Güçlenmek) }\end{array}$ & $\begin{array}{l}\text { Ön test-son test kontrol } \\
\text { gruplu yarı deneysel } \\
\text { desen }\end{array}$ & $\begin{array}{l}\text { Doğru ve sağlıklı bilgileri bir profesyonelden almanın ve bir arada } \\
\text { konuşabilme ihtiyacının güvenli sınıf ortamında karşılanmasının, } \\
\text { ergenlerle çalışırken eğitimin etkililiğini artıran faktörler olabileceği ileri } \\
\text { sürülmüştür. }\end{array}$ \\
\hline $\begin{array}{l}\text { Altafim, Pedro } \\
\text { ve Beatriz, } \\
2016\end{array}$ & $\begin{array}{l}\text { Eğitim- } \\
\text { Bilgilenmek } \\
\text { (Güçlenmek) }\end{array}$ & $\begin{array}{l}\text { Ön test-son test tek } \\
\text { gruplu yarı deneysel } \\
\text { desen }\end{array}$ & $\begin{array}{l}\text { Ebeveynlere verilen "iyi ebeveynlik" eğitimlerinin çocuğun davranışlarını } \\
\text { yönetmek, saldırganca tutumu azaltmak ve çocuğa kötü muameleyi } \\
\text { önlemede evrensel ve iyi stratejiler olduğu gösterilmiştir. }\end{array}$ \\
\hline $\begin{array}{l}\text { Alvarez, } \\
\text { Padilla ve } \\
\text { Máiquez, } 2016\end{array}$ & $\begin{array}{l}\text { Eğitim- } \\
\text { Bilgilenmek } \\
\text { (Güçlenmek) }\end{array}$ & $\begin{array}{l}\text { Karma desen: Ön test- } \\
\text { son test kontrol gruplu } \\
\text { yarı deneysel desen. } \\
\text { İlişkise (Regresyon) } \\
\end{array}$ & $\begin{array}{l}\text { Riskli aileler söz konusu olduğunda ve ebeveynde tutum değişikliği } \\
\text { sağlamak hedeflendiğinde, uygulama türünden bağımsız biçimde, nitelikli } \\
\text { uygulama sürecini oluşturan temel unsurları değerlendirmenin önemi } \\
\text { tartışılmıştır. }\end{array}$ \\
\hline $\begin{array}{l}\text { Cluver vd., } \\
2016\end{array}$ & $\begin{array}{l}\text { Kötü } \\
\text { Muameleyi } \\
\text { Durdurma- } \\
\text { (Sirlara Veda) }\end{array}$ & $\begin{array}{l}\text { Karma desen: Ön test- } \\
\text { son test kontrol gruplu } \\
\text { yarı deneysel desen. } \\
\text { İlişkisel (Yapisal Eşitlik } \\
\text { Modellemesi) }\end{array}$ & $\begin{array}{l}\text { Yürütülen müdahale programlarında, ailelerin ekonomik yönden } \\
\text { güçlendirecek becerilerin öğretimiyle desteklenmesinin özellikle düşük } \\
\text { ve orta gelişmiş ülkelerde çocuğa karşı işlenen suçları sonlandırma } \\
\text { potansiyeli vurgulanmıştır. }\end{array}$ \\
\hline $\begin{array}{l}\text { Covell, Howe } \\
\text { ve McNeil, } \\
2010\end{array}$ & $\begin{array}{l}\text { Eğitim- } \\
\text { Bilgilenmek } \\
\text { (Güçlenmek) }\end{array}$ & $\begin{array}{l}\text { Karma desen: Müdürler } \\
\text { ve iki bölge program } \\
\text { yürütücüsü ile } \\
\text { derinlemesine } \\
\text { görüşmeler. Ö̈̆gretmenler } \\
\text { ile anketler }\end{array}$ & $\begin{array}{l}\text { Hak temelli eğitiminin başarısını farklılaştıran en temel unsurun okul } \\
\text { idarecisinin yaklaşımı olduğu, fakat tüm diğer temel değişkenleri } \\
\text { belirlemenin çocuk haklarıyla tutarlı eğitimin uygulanmasını } \\
\text { kolaylaştıracağı önerilmiştir. }\end{array}$ \\
\hline Dion, vd., 2016 & $\begin{array}{l}\text { Psiko-sosyal } \\
\text { Müdahale } \\
\text { (Endişeleri } \\
\text { Azaltmak) }\end{array}$ & $\begin{array}{l}\text { en: Geriye } \\
\text { lamsal } \\
\text { Çok düzeyli } \\
\text { odeli }\end{array}$ & $\begin{array}{l}\text { Tartışma, kötü muameleye erken müdahalenin önemini vurgularken } \\
\text { arkadaş desteğinin psikolojik strese karşı teskin edici rolünü de ortaya } \\
\text { koymaktadır. }\end{array}$ \\
\hline $\begin{array}{l}\text { Fantuzzo vd., } \\
1996\end{array}$ & $\begin{array}{l}\text { Psiko-sosyal } \\
\text { Müdahale } \\
\text { (Endişeleri } \\
\text { Azaltmak) }\end{array}$ & $\begin{array}{l}\text { Ön test-son test kontrol } \\
\text { gruplu yarı deneysel } \\
\text { desen }\end{array}$ & $\begin{array}{l}\text { Kötü muamaleye müdahalede gelişimsel bakış açısıyla ve çocuğun } \\
\text { ekolojisinde kendisi için önemli unsurları (oyun, arkadaşlarla sosyal } \\
\text { etkileşimler) gözeterek yaklaşmak önerilmiştir. }\end{array}$ \\
\hline $\begin{array}{l}\text { Glasser vd., } \\
2001\end{array}$ & $\begin{array}{l}\text { Kötü } \\
\text { Muameleyi } \\
\text { Durdurma- } \\
\text { (Sirlara Veda) }\end{array}$ & $\begin{array}{l}\text { Geriye dönük } \\
\text { (retrospektif) klinik vaka } \\
\text { notu incelemesi. }\end{array}$ & $\begin{array}{l}\text { "İstismara uğrayan istismar eder" inanışının sadece çalışmaya katılan bir } \\
\text { grup erkek için geçerli olduğu tartışılmıs ve fail yetişkin erkeklerin kendi } \\
\text { failllerinin çoğunlukla kadın akrabaları olduğunu bildirdikleri } \\
\text { vurgulanmıştır. }\end{array}$ \\
\hline $\begin{array}{l}\text { Green, vd., } \\
2020\end{array}$ & $\begin{array}{l}\text { Eğitim- } \\
\text { Bilgilenmek } \\
\text { (Güçlenmek) }\end{array}$ & $\begin{array}{l}\text { Karma desen: Boylamsal } \\
\text { bir çalışma. Ön test-son } \\
\text { test kontrol gruplu yarı } \\
\text { deneysel desen }\end{array}$ & $\begin{array}{l}\text { Müdahale programlarının aynı aileden çocuk ve ebeveyn olmak üzere her } \\
\text { iki neslin birlikte ele alınması ve çocuk küçük yaştayken başlatılmasının, } \\
\text { yaşamın ilerleyen dönemlerinde aile içi çocuk istismar ve ihmali } \\
\text { olasılığını azaltabileceği vurgulamaktadır. }\end{array}$ \\
\hline $\begin{array}{l}\text { Hubel, Rostad, } \\
\text { Self-Brown ve } \\
\text { Moreland, } 2018\end{array}$ & $\begin{array}{l}\text { Eğitim- } \\
\text { Bilgilenmek } \\
\text { (Güçlenmek) }\end{array}$ & $\begin{array}{l}\text { Ön test-son test kontrol } \\
\text { gruplu yarı deneysel } \\
\text { desen }\end{array}$ & $\begin{array}{l}\text { Çocuğu kötü muameleden korurken, ebeveyn eğitimlerini programın } \\
\text { hedefindeki ebeveyn grubunun ihtiyaçları özelinde uyarlanması ve } \\
\text { davranışsal ebeveynlik programlarının farklı gruplarda (ör. Ergen } \\
\text { ebeveynler) sinanmasının yararları tartışılmışıtı. }\end{array}$ \\
\hline $\begin{array}{l}\text { Karale Malgi, } \\
\text { Mohite ve } \\
\text { Choudhari, } \\
2020\end{array}$ & $\begin{array}{l}\text { Eğitim- } \\
\text { Bilgilenmek } \\
\text { (Güçlenmek) }\end{array}$ & $\begin{array}{l}\text { Ön test-son test tek } \\
\text { gruplu yarı deneysel } \\
\text { desen }\end{array}$ & $\begin{array}{l}\text { Hindistanda annelerin çocuk istismarı hakkında farkındalı̆̆ını artıran } \\
\text { programlara ihtiyaç vurgulanmıştır. }\end{array}$ \\
\hline $\begin{array}{l}\text { Kwak, } \\
\text { Mihalec- } \\
\text { Adkins, Mishra } \\
\text { ve Christ, } 2018\end{array}$ & $\begin{array}{l}\text { Psiko-sosyal } \\
\text { Müdahale } \\
\text { (Endişeleri } \\
\text { Azaltmak) }\end{array}$ & $\begin{array}{l}\text { İlişkisel desen: Ulusal } \\
\text { veri üzerinden boylamsal } \\
\text { tarama }\end{array}$ & $\begin{array}{l}\text { Belirli türden kötü muameleye maruz kalan ergenlerin akranlarıyla bir } \\
\text { arada olabilecekleri organize faaliyetlere katılımının gelişimleri } \\
\text { üzerindeki olası yararları ve riskleri ortaya konmuştur. }\end{array}$ \\
\hline $\begin{array}{l}\text { Lachman vd., } \\
2017\end{array}$ & $\begin{array}{l}\text { Kötü } \\
\text { Muameleyi } \\
\text { Durdurma- } \\
\text { (Surlara Veda) }\end{array}$ & $\begin{array}{l}\text { Ön test-son test kontrol } \\
\text { gruplu yarı deneysel } \\
\text { desen }\end{array}$ & $\begin{array}{l}\text { Kötü muamaleye müdahale için oluşturulacak yeni ebeveyn eğitim } \\
\text { programlarının olası etkililiğini belirlemek için, sosyal öğrenme temelli } \\
\text { mevcut çabalardan elde edilen bilimsel sonuçlardan faydalanılmas } \\
\text { önerilmiştir. }\end{array}$ \\
\hline $\begin{array}{l}\text { Lam, Zwart, } \\
\text { Chahal, Lane } \\
\text { ve Cummings, } \\
2018\end{array}$ & $\begin{array}{l}\text { Psiko-sosyal } \\
\text { Müdahale } \\
\text { (Endișeleri } \\
\text { Azaltmak) }\end{array}$ & $\begin{array}{l}\text { İlişkisel desen: Ulusal } \\
\text { veri üzerinden geriye } \\
\text { dönük enlemesine } \\
\text { kesitsel araştırma }\end{array}$ & $\begin{array}{l}\text { Çocuklara uygulanan eğitim programın etkililiği değerlendirilirken } \\
\text { ebeveynlerden ve doz-tepki yaklaşımından yararlanılabileceği, daha } \\
\text { güçlü kanıtların toplanabilmesini sağlamak için araştırma planlanırken } \\
\text { deneysel desenden yararlanılması ve program öncesi önlemlerin } \\
\text { planlanmasına dikkat çekilmektedir. }\end{array}$ \\
\hline
\end{tabular}


Tablo 1 (Devamı). Çocuğa Kötü Muamelenin Olumsuz Etkilerinden Koruyucu Unsurları Konu Edinen Makaleler*

\begin{tabular}{|c|c|c|c|}
\hline Kaynak** & $\begin{array}{l}\text { Koruyucu } \\
\text { temel unsur }\end{array}$ & Araştırma deseni & Tartışma \\
\hline $\begin{array}{l}\text { Lee ve Chou, } \\
2016\end{array}$ & $\begin{array}{l}\text { Psiko-sosyal } \\
\text { Müdahale } \\
\text { (Toplumsal } \\
\text { destek) }\end{array}$ & $\begin{array}{l}\text { Ön test-son test kontrol } \\
\text { gruplu yarı deneysel } \\
\text { desen }\end{array}$ & $\begin{array}{l}\text { Taiwan'da sağlık hizmeti veren en büyük profesyonel grup olan } \\
\text { hemşirelerin öz-etkililiği ile çocuğa kötü muameleyi } \\
\text { davranışsını geliştirmede "Hemşireler için Çocuk İstismarı ve İhmali } \\
\text { Eğitim Programı" nın etkililiği ortaya konmuş ve öncül korelasyonel } \\
\text { çalışmaların bulguları netleştirilmiştir. }\end{array}$ \\
\hline $\begin{array}{l}\text { Lee, Kirkland, } \\
\text { Miranda-Julian, } \\
\text { ve Greene, } \\
2018\end{array}$ & $\begin{array}{l}\text { Psiko-sosyal } \\
\text { Müdahale } \\
\text { (Toplumsal } \\
\text { destek) }\end{array}$ & $\begin{array}{l}\text { Ön test-son test kontrol } \\
\text { gruplu yarı deneysel } \\
\text { desen }\end{array}$ & $\begin{array}{l}\text { Kötü muameleyi önlemek ve çocuk refahını artırmayı hedefleyen } \\
\text { programlarda üçüncül bir strateji olarak annelere ev ziyaretlerinin } \\
\text { değerlendirilmesini ve farklı gruplarda (ör. çok doğum yapan veya çocuk } \\
\text { koruma sistemine kayıtlı olmayan annelerde) bu stratejinin etkililiğinin } \\
\text { sinanması önerilmektedir. }\end{array}$ \\
\hline $\begin{array}{l}\text { Morris vd., } \\
2016\end{array}$ & $\begin{array}{l}\text { Eğitim- } \\
\text { Bilgilenmek } \\
\text { (Güçlenmek) }\end{array}$ & $\begin{array}{l}\text { Ön test-son test kontrol } \\
\text { gruplu yarı deneysel } \\
\text { desen }\end{array}$ & $\begin{array}{l}\text { Okul temelli istismarı önleme programlarında, çocuk istismarı ve ihmali } \\
\text { oranları yüksek topluluklar için, uyarlamaların gerekebileceğine dikkat } \\
\text { çekilmiştir. }\end{array}$ \\
\hline $\begin{array}{l}\text { Oppenheim- } \\
\text { Weller ve } \\
\text { Zeira, } 2018\end{array}$ & $\begin{array}{l}\text { Psiko-sosyal } \\
\text { Müdahale } \\
\text { (Toplumsal } \\
\text { destek) }\end{array}$ & $\begin{array}{l}\text { Derinlemesine } \\
\text { görüşmeler }\end{array}$ & $\begin{array}{l}\text { Bir müdahale programı kanıta dayalı biçimde geliştirillmiş bile olsa; } \\
\text { geliştirildiğinden farklı bir bağlamda uygulanırken, katılımcıların } \\
\text { programa bağlılığını etkileyebilecek potansiyel unsurların belirlenmesinin } \\
\text { ve uygulamanın bağlama özel uyarlaması önerilmektedir. }\end{array}$ \\
\hline $\begin{array}{l}\text { Shenderovic, } \\
\text { Cluver, Eisner } \\
\text { ve Murray, } \\
2020\end{array}$ & $\begin{array}{l}\text { Eğitim- } \\
\text { Bilgilenmek } \\
\text { (Güçlenmek) }\end{array}$ & $\begin{array}{l}\text { İlişkisel-Boylamsal çok } \\
\text { düzeyli desen }\end{array}$ & $\begin{array}{l}\text { Düşük ve orta gelirli ailelerin çoğunluğu oluşturduğu ülkelerdeki } \\
\text { çocuklara kötü muameleyi azaltmayı ve ebeveynlik becerilerini } \\
\text { geliştirmeyi amaçlayan ebeveynlik müdahalelerinin, çeşitli ve yoğun } \\
\text { ekonomik zorluklarla karşı karşıa kalan ailelerde de etkili olabileceği } \\
\text { vurgulanmaktadır. }\end{array}$ \\
\hline $\begin{array}{l}\text { Taal ve } \\
\text { Edelaar, } 1997\end{array}$ & $\begin{array}{l}\text { Eğitim- } \\
\text { Bilgilenmek } \\
\text { (Güçlenmek) }\end{array}$ & $\begin{array}{l}\text { Ön test-son test kontrol } \\
\text { gruplu yarı deneysel } \\
\text { desen }\end{array}$ & $\begin{array}{l}\text { Cinsel istismarı önleme hedefindeki "Güven Hakkı" programının } \\
\text { davranışsal ve tutumsal etkilerinin bazıları } 30 \text { dakika, bazıları } 1 \text { saat süren } \\
\text { ve } 6 \text { hafta boyunca haftada bir veya iki defa verilen derslerin sayısı veya } \\
\text { süresi uzatılarak iyileştirilebileceğini önerilmektedir. }\end{array}$ \\
\hline $\begin{array}{l}\text { Thomas ve } \\
\text { Zimmer- } \\
\text { Gembeck, } 2012\end{array}$ & $\begin{array}{l}\text { Psiko-sosyal } \\
\text { Müdahale } \\
\text { (Endişeleri } \\
\text { Azaltmak) } \\
\end{array}$ & $\begin{array}{l}\text { Ön test-son test kontrol } \\
\text { gruplu yarı deneysel } \\
\text { desen }\end{array}$ & $\begin{array}{l}\text { Standart terapi programlarını özel gruplara uygulamak için zaman ve para } \\
\text { gerektiren uyarlamalara girişilmeden önce, bu standart hizmetlerin özel } \\
\text { gruplara uygun olup olmadığına dair bir değerlendirmenin yapılmasının } \\
\text { önemli olduğu vurgulanmaktadır. }\end{array}$ \\
\hline $\begin{array}{l}\text { Turner, } \\
\text { Robbins, } \\
\text { Rowlands ve } \\
\text { Weaver, } 2017\end{array}$ & $\begin{array}{l}\text { Psiko-sosyal } \\
\text { Müdahale } \\
\text { (Toplumsal } \\
\text { destek) }\end{array}$ & $\begin{array}{l}\text { Ön test-son test kontrol } \\
\text { gruplu yarı deneysel } \\
\text { desen Basamaklı karma } \\
\text { desen }\end{array}$ & $\begin{array}{l}\text { "İşlevsel Aile Terapisi-Çocuk Refahı" programının, ailelerin çocuk } \\
\text { koruma sisteminde sunulan hizmeti tamamlamada daha verimli olduğu ve } \\
\text { müdahale hedeflerine ulaşmada ise "Olağan Bakım" programından daha } \\
\text { etkili olduğu ve olumsuz sonuçlardan kaçınmaya yol açtı̆̆ } \\
\text { vurgulanmıştır. }\end{array}$ \\
\hline $\begin{array}{l}\text { Yılmaz Irmak, } \\
\text { Kiziltepe, } \\
\text { Aksel, Güngör } \\
\text { ve Eslek., } 2018\end{array}$ & $\begin{array}{l}\text { Eğitim- } \\
\text { Bilgilenmek } \\
\text { (Güçlenmek) }\end{array}$ & $\begin{array}{l}\text { Ön test-son test kontrol } \\
\text { gruplu yarı deneysel } \\
\text { desen Basamaklı karma } \\
\text { desen }\end{array}$ & $\begin{array}{l}\text { "Mika ile Kendimi Korumayı Öğreniyorum" programının çalışmaya } \\
\text { katılan çocuklarda mevcut bilgilerin niteliğini ve niceliğini değiştirmede } \\
\text { etkili (dokunma ve sır) ve daha az etkili olduğu (istismarcının kimliği ve } \\
\text { sır) yönleri belirtilerek, uygulanacak yeni eğitimlerde uyarlamalar } \\
\text { önerilmektedir. }\end{array}$ \\
\hline
\end{tabular}

Ulaşılan görgül çalışma, derleme ve raporlarda çocuğa kötü muamelede uygulanan koruma programlarının basitçe pratik adımların betimlenmesinin ötesine geçen ve programın verimini ve etkinliğini ele alan az sayıda kontrollü çalışmanın düzenlenmesi ve etkili önleyici unsurlara kapsayıcı açıklamalar üretilmemesi nedenleriyle araştırmalar eleştirilmektedir (ör. Cluver vd., 2020; Oppenheim-Weller ve Zeira, 2018; Öztürk, 2020). Bu bulgular temelinde; ülkemizde çocuğa kötü muamele alanında çalışan profesyoneller için, çocuğa kötü muameyi oluşturan etkenleri ve çocuğu korumak için dikkat edilmesi gereken önemli ve farklı düzeylerde unsurları bilimsel gerekçeleri ile birlikte tanıtan bir derleme çalışması oluşturma ihtiyacı belirmiştir. Ulaşabildiğimiz kadarı ile bu çalışma; bildirim yükümlülüğü olan meslek gruplarına çocuğa kötü muameleye müdahalede zarar verici ve koruyucu unsurların neler olabileceğini bilimsel kanıtlar ile tanıtmak amacını taşıyan ilk çalışmadır. Bu derleme çalışmasında ulaşılan bulguların ve bilgilerin sistemli biçimde sunulması amacına ulaşmada Belsky’nin ekolojik bakış açısı kapsayıcı bir kavramsal çerçeve olarak belirlenmiştir. 


\section{Çocuğu Kötü Muamele Karşısında GÜVENDE Tutmak}

Çocuğa kötü muameleyi anlamak için bir neler yapılabileceği GÜVENDE olarak kısaltılan, kötü muameleyi tanımak ve çocuğu sosyo-psikolojik açıdan desteklemek amacına ulaştıran dört temel unsur ile açıklanacaktır. Her bir unsura dair başlık altında yer verilen açıklama düzeyleri, Belsky’nin (1980) öne sürdüğü dört ekolojiyi mümkün olduğu oranda kapsamaktadır. Kısaca güçlenmek olarak tanımlanan ilk başlikta, kötü muameleyi önlemenin temel yolu olan bilgilenmenin hedefi, kapsamı ve ülkemizdeki mevcut durumu ele alınmaktadır. Takip eden üç temel unsur olan, strlara veda etmek, endişelerle baş etmek ve toplumsal destek başlıkları altında ise nitelikli müdahale sürecine dair bir kavrayış oluşturmayı hedefleyen kapsamlı bilgi sunulmaktadir.

\section{İlk temel unsur: Kötü muamele karşısında güçlenmek için bilgilenmek}

Çocukları ihmal ve istismardan koruyabilmek için öncelikle "çocuk hakları ve hak ihlalleri konularında bilgilenmek" önerilmektedir. Çocuğu istismar ve ihmale karşı koruyucu eğitimler; bir toplumda çocuğun güvende olabilmesi için ebeveynlerin ve çocukların neler yapabileceklerine, çocuk gelişimi ve hakları konularındaki temel bilgileri kapsar. Ailelerin ve öğretmenlerin çocuk haklarına farkındalıkları ve yanı sıra çocuğun kendi hakkını savunabilmesi de, çocuğu ihmal ve istismardan korur ve güçlendirir (Öztürk, 2017).

Dünyanın oldukça farklı ülkelerinde yürütülen bilgilendirmelerin hedefindeki gruplar incelendiğinde, kötü muamele ile ilgili eğitimlerin çoğunlukla ebeveynlere yönelik düzenlendiği (ör. Alvarez, Padilla ve Máiquez, 2016, Altafim, Pedro ve Beatriz, 2016; Cluver vd., 2016; Lachman vd., 2017; Lee, Kirkland, Miranda-Julian ve Greene, 2018; Y1ldırım ve Kublay, 2016) görülmektedir. Doğrudan çocukların kötü muamele hakkında eğitildiği programların ise görece yakın zamanda tarihlendiği (ör. Akyol ve Kutlu, 2019; Lam, Zwart, Chahal, Lane ve Cummings, 2018; Morris vd., 2016;) ve çocuklara formal yollarla okullarda eğitim vermenin ise daha az yaygın olduğunu (Akyol ve Kutlu, 2019) da belirlenmektedir. Çocuğa istismarı ve ihmali önlemek adına erken çocukluk döneminden ergenliğe değin çocukları olan ebeveynlere verilen eğitimlerde; çocuk istismarı ve ihmali hakkında bilgilendirme (Alvarez vd., 2016; Karale, Malgi, Mohite ve Choudhari, 2020), iyi ana-babalık becerileri geliştirme (ör. dişsallaştırma sorunları olan çocuklara yaklaşım) (Altafim vd., 2016; Cluver vd., 2016; Lachman vd., 2017; Lee, Kirkland, Miranda-Julian, ve Greene, 2018; Yıldırım ve Kublay, 2016) ve çocukta optimal gelişimi sağlamak (Green vd., 2020; Oppenheim-Weller ve Zeira, 2018) hedeflerinden birine veya birden fazlasina (Cluver vd., 2020; Hubel, Rostad, Self-Brown ve Moreland, 2018; Karale, Malgi, Mohite ve Choudhari, 2020; Lachman vd., 2017; Lachman vd., 2020) yer verildiği ve etkili oldukları görülmektedir. Örneğin, çocuk istismarının endişe konusu olduğu ülkelerden olan Hindistanın Karad ilinde; 3-6 yaşlarındaki çocukların devam ettiği Arganwadi merkezlerindeki 100 çocuğun anneleri ile yürütülen bir çalışmada, istismar hakkında anneleri bilgilendirmeyi içeren "Planlı Öğretim Programı" nın annelerin bilgi düzeyindeki farklılaşmaya yol açıp açmadığı incelenmiştir (Karale vd., 2020). Araştırmanın bulguları, uygulanma öncesinde annelerin orta düzeyde olduğunu bildirdikleri çocuk istismarı ve istismarını önlemeye dair bilgi düzeylerinin, programın uygulanması sonucunda anlamlı olarak artarak "iyi düzeye" ulaştığını göstermiştir. Annelerin çocuk istismarı hakkında sahip olduklarını bildirdikleri temel bilgi düzeyinin bilgi düzeyinin; eğitim düzeylerine, ailenin aylık gelirine ve mensup oldukları dine göre farklılaştığı fakat ailenin büyüklüğü, annenin yaşı, çocuk sayısı ve çocuk istismarına dair 
edinilen bilginin kaynağı gibi diğer bir grup demografik değişkene bağlı olarak farklılaşmadığı da bulunmuştur.

$\mathrm{Bu}$ müdahale çalışmalarında yürütülen müdahale ve eğitimlerin "işe yaramasını" sağlayan ve engelleyen unsurları ile kötü muamaleyi önlemede rolleri de araştırılmıştır. Örneğin, Alvarez ve diğerleri (2016), 0-5 yaş aralığında çocuğu olan genç İspanyol (Kanarya adalı) annelerle yürütükleri ve çocuğa kötü muameleyi önleme hedefi olan "Ailede Mutlu Büyümek" programının çocuğa karşı tutum değişimi üzerinde etkililiğini sağlayan özelliklerini ele almıştır. Kötü muamele oluşturan çevre açısından hem yüksek psiko-sosyal risk taşıyan hem de düşük psikososyal risk taşıyan anne gruplarından elde edilen bulgulara göre; katılımcı ebeveynin programa bağlılı̆̆ının, sunulan eğitim materyalinin nitelikli oluşunun, katılımcının programdan memnuniyetinin ve oluşturulan olumlu görüşme ikliminin ebeveynlerde olumlu tutum değişikliğine yol açabildiği ortaya konmuştur. Risk altındaki bir grup olan Oklahomalı ergen ebeveynler ile 21 yaşının altındaki çocukları olan yetişkin ebeveynlerin yer aldığı bir diğer çalışmada ise SafeCare'ın ergen ebeveynlerde etkililiği ele alınmıştır (Hubel, Rostad, Self-Brown ve Moreland, 2018). SafeCare, Amerika'da birden fazla eyalette koruma sisteminde uygulanan ve kanıta dayalı yetişkin ebeveyn eğitimi programıdır. Araştırma sonucunda ergen ebeveynlerle SafeCare'in standart biçimde kullanımının; yetişkin ebeveynlerde ulaşılan çocuk refahını ihlal etme suçunu yeniden işlemeyi önleme, depresyon ve çocuk istismarı potansiyelinde azalma ve program memnuniyeti ve katılımı gibi hizmet hedeflerine ulaşmayı sağlayamadığı saptanmıştır. Yanı sıra ergen ebeveynlerde çocuğa kötü muamaleyi azaltmada, SafeCare grubuna atanmanın, Oklahoma eyaletinin genel olarak sağladığı diğer bir ev ziyareti uygulamasına atanma koşulundan farklı bir etkisi de ortaya çıkmamıştır. Ergen ebeveynlerde SafeCare sonlandırıldığında ve takip eden altı ayın içinde alınan ölçümlerde farklılaşan ve olumlu bir sonuca ulaştıramadığ da bulunmuştur. Geniş ölçekli bir diğer program uyarlama çalışmasını ise, Shenderovich ve diğerleri (2020) Güney Afrika'da Doğu Kap ilinden kırsal/kentsel konutlarda yaşayan 10-18 yaşındaki ergenler ve onların bakım verenlerinden oluşan 552 çiftin katılımı ile gerçekleştirmiştir. Bu çalışmada çocuğa, bakım verene, haneye ve Güney Afrika toplumuna ilişkin bir grup özelliğin Sinovuyo programının "Gençler için Sinovuyo" uyarlamasının etkililiği üzerindeki olası düzenleyici etkilerinin sınanması amaçlanmıştır. Çocuklara kötü muamele hakkında bilgilendiren ve ebeveynlik uygulamalarına odaklanan bir müdahale programı olan Sinovuyo'nun gençlerle başarısı üzerinde olası etkileri olabilecek "düzenleyiciler" ise; çocuğun dışsallaştırma sorunu, ebeveynin çocukluğunda kötü muameleye uğrama öyküsü, ebeveynin HIV pozitif öyküsü, aile içi şiddet maruziyeti ve ekonomik dezavantaj olarak belirlenmiştir. Programın uygulandığı ebeveynler ve onların ergen çocuklarının kötü muamele, olumlu ebeveynlik, ilgili ebeveynlik ve ebeveynin çocuğu izlemesi hakkındaki özbildirimlerinden programın başlangıcında, programın bitişini takiben 1 ay ve 5-9 ay içinde üç zamanlı olarak yararlanılmıştır. Çoklu karşılaştırma testi için düzeltme yapıldıktan sonra elde edilen bulgular, hiçbir düzenleyici etkinin istatistiksel olarak anlamlı düzeye ulaşmadığını göstermiştir. Katılımcıların bildirdikleri fiziksel ve psikolojik kötü muamalede puanlarında ise programı takip eden ilk 1 ay içindeki ciddi azalma ve sonrasında 5-9. aylarda saptanan hafif düzeyde artış gözlenmiştir. Bu bulgular bir arada değerlendirildiğinde, standart müdahalenin etkililiğinin ancak hedeflendiği grubun ihtiyaçları doğrultusunda uyarlama yapılmasıyla artabileceğine işaret etmektedir. Cluver ve diğerlerinin (2016), 10-18 yaşlarında Güney Afrikalı ergenler ve birincil bakım verenlerin katılımı ile düzenledikleri araştırmalarında ise Dünya Sağlık Örgütü ve UNICEF ile birlikte tasarlanan "Gençlerin Yaşam Boyu Sağlığı için Ebeveynlik" isimli sosyal öğrenme temelli iyi ebeveynlik programının cocuğa kötü muamelevi önlevici niteliklerini ele alınmıstır. Ergenlerden 
ve ebeveynlerden alınan ölçümlere uygulanan yol analizleri sonuçları, artan olumlu ebeveynlik, ebeveynin zihinsel iyioluşundaki ilerleme, ebeveynin bağımlılıkla ilgili maddelerden uzak durması ve ailenin ekonomik koşullarında iyileşme olarak belirlenen dört aracı üzerinden birincil bakım verenin ergene kötü muamelesinin azaldığını göstermiştir. Green ve diğerleri (2020) doğumdan üç yaşına kadar Early Head Start (EHS) Araştırma ve Değerlendirme Projesi'nde (EHSREP) yer alan 2794 çocuğa ulaşmış ve yaşamlarının ilk 15-yılında kötü muameleyi önlemede, doğumdan üç yaşına değin çocuklara hizmet veren EHS programının etkililiğini incelemiştir. Bulgular, erken yaştaki çocuklar için bir müdahale program olan EHS'ye rastgele atanan grupta; aile içi çatışmaların ve stresin başarılı bir şekilde azaltılabildiğini ve olumlu, duygusal olarak duyarlı ebeveynliğin ve çocuk gelişiminin desteklenebildiğini ortaya koymuştur. İncelenen çocuk koruma sistemleri kayıtları sayesinde; programa iki yaşından itibaren dâhil olan ve 15 yaşına değin takip edilen çocukların, kontrol grubu ile karşılaştırıldığında, kötü muameleye uğrama ve çocuk koruma sistemine dâhil olma oranlarının anlamlı biçimde daha düşük olduğu belirlenmiştir. $\mathrm{Bu}$ bulgular çocukların yaşamlarının erken dönemdeki müdahalenin olumlu etkisinden çocuklukları boyunca aile içi ilişkilerin farklı boyutları (ör. iyi ebeveynlik) üzerinden yararlandıklarını ve erken müdahale sayesinde kötü muameleden korunabildiklerini göstermektedir.

Çocukları istismar ve ihmalden korunma konusunda bilgilendiren programların hitap ettiği yaş grupları ve içerikleri incelendiğinde ise; çoğunlukla ortaokul ve lise öğrencilerine hitap edildiği ve istismar ve ihmalden korunma becerilerini geliştirmek (Lam, Zwart, Chahal, Lane ve Cummings, 2018; Morris vd., 2016), kendini açmayı desteklemek (Yılmaz Irmak, Kizıltepe, Aksel, Güngör ve Eslek., 2018) ve cinsel eğitim ve istismar hakkında bilgi vermek (Akyol ve Kutlu, 2019) konuları üzerine odaklanıldığı gözlenmektedir. Yılmaz Irmak ve diğerlerinin (2018), çalışmasında cinsel istismarı önlemek amacıyla okulöncesi dönemdeki çocuklar için ülkemizde ilk defa geliştirilen okul temelli "Mika ile Kendimi Korumayı Öğreniyorum" eğitim programının etkiliği incelenmiştir. Ardışı 5 günde uygulanan her biri 25-30 dakikalık 5 oturumdan oluşan çalışmaya katılan çocukların bilgileri ve ebeveynlerin çocuklarının duygusal ve sosyal tepkileri ve beden memnuniyetlerini içeren bir grup davranışlarına yönelik bildirimleri incelenmiştir. Çalışma başında çocuklar cinsel istismara yönelik doğru bilgileri temelinde 3 statü grubuna ayrılmıştır. Bulgular, programa katılan gruptaki çocuklar arasından, programın başında kendine dokunulmasını ve sır olarak saklanmasını doğru bulanlar statüsündekilerin (Statü 3) .35'i ve kendine dokunulmasını yanlış bulup yine de sır olarak tutanlar statüsünde yer alanların (Statü 2) .70'ı program sonunda kendini korumayı bilenler statüsüne (Statü 1) geçiş yapmıştır. Kontrol grubu için statüler arası geçiş oranları ise çok daha düşüktür. Her iki grupta yer alan ebeveynler ise, çocukların duyguları hakkında kendileriyle konuşma davranışlarında artışa işaret etmiştir. Program sonunda başlangıcına kıyasla eğitim grubundaki çocuklar için öfke ve beden memnuniyetinde artış ve kontrol grubundaki çocuklar için ise uykuya geçmede güçlük ve karanlık korkusu düzeylerinde artış saptanmıştır (Yılmaz Irmak vd., 2018). Ülkemizden bir diğer çalı̧̧mada ise Akyol ve Kutlu (2019), Sivas ili Kangal ilçesinden düşük sosyo-ekonomik düzeyden gelen 8 . sınıf öğrencileri ile her biri 40 dakika süren 8 oturumluk bir "Cinsel Sağlik Psiko-Eğitimi" çalışması uygulamıştır. Çalışma sonucunda; deney grubunun $(\mathrm{n}=24)$ kontrol grubuna ( $\mathrm{n}=24)$ göre; ergenlik dönemi ve toplumsal cinsiyet konularında bilgisinin olumlu yönde $\operatorname{arttığ1~ve~istismar~(fiziksel,~duygusal~ve~cinsel)~konusunda~gruplar~arası~anlamlı~bir~farkın~ise~}$ olmadığ bulunmuştur. Çoğu çalışmada çocuğun içinde bulunduğu gelişimsel döneme uygun öğretim hedeflerine ulaşıldığı görülmektedir. Araştırmacılar; erken çocukluk döneminde çocuğun duygularını ve bedenini tanıması, uygun olan ve uygun olmavan dokunusları avırt edebilmesi. 
kendini korumaya yönelik davranışları öğrenmesi ve iyi ve kötü sırları fark edebilmesi (Yılmaz Irmak vd., 2018), orta çocukluk döneminde çocuğun güvenilir ve güvenilmez insanları ayırt etmesi, güvenli ve güvensiz durumları fark etmesi, problem çözme becerileri, atılganlık eğitimi ve uygun kendini açma yöntemlerini öğrenmesi (Morris vd., 2016) hedeflerinin gerçekleştiğini bildirmektedir. Ergenlik döneminde ise ek olarak toplumsal cinsiyet ve ergenlik dönemi ile ilgili bilgi düzeylerinin artması (Akyol ve Kutlu, 2019) da sağlanmaktadır. Okulların müfredat ve öğretim programlarında, hak eğitimi kapsamında istismar ve ihmale yönelik içerik mevcuttur. Farklı ülkelerde amacı formal eğitim dönemindeki çocukların insani değerleri, vatandaşlık hakkını ve eşitliği içselleştirebilmesinin öncelikle hedeflendiği hak eğitimi derslerinde (Covell, Howe ve McNeil, 2010) veya sağlik derslerinde öğretmenler çocuklara istismar ve ihmal konusunda bilgilendirme yapmaktadır (Taal ve Edelaar, 1997). Covell ve diğerleri (2010) Hampshire, İngiltere'de çocuk hakları eğitimi verilen 18 okuldan 127 öğretmenin katılımı ile düzenledikleri araştırmalarında, çocuk haklarını müfredata ve tüm okul politikalarına ve uygulamalarına dâhil etmede çok başarılı olan okulları incelemiş ve uygulama çabalarını ve deneyimlerini daha az başarılı olan okullarla karşıllaştırmıştır. Yapılan ayrıntılı değerlendirmelere göre; hak eğitimini doğrudan müdürlerinin aldığı, öğretmen ve çalışanların hak temelli çalışmalarında okul müdürü tarafından desteklendiği, programın uygulanmaya başlamasını takip eden ilk yıl içinde geniş bir öğretmen desteği bulduğu okulların haklara saygı gösterme konusunda başarılı oldukları bulunmuştur (Covell vd., 2010).

Kötü muameleyi ortaya çıkmadan önlemede eğitimin rolüne önem veren ülkeler, bunu okullarla işbirliği ile sağladıkları ücretsiz hizmetler yoluyla gerçekleştirmektedir. Hollanda Amsterdam'da Cinsel Şiddeti Önleme Konseyi'nin girişimi ile düzenlenen ve okul temelli bir cinsel istismarı önleme programını olan "Güven Hakkı" nın etkililiği, 8 ila 12 yaşları arasındaki öğrenciler arasından programa katılan 161 çocuk ve kontrol grubundaki 131 öğrenciden sağlanan verilerin karşılaştırılması ile değerlendirilmiştir. Araştırmanın sonuçları, hem büyük hem de küçük çocuklarda kısa süreli olumlu etkiler olduğunu; önleme programına katılan çocuklarda cinsel istismar karşısında güvenli stratejilerinin seçiminde artış ve istismarın kendi kontrollerinin olduğu hissinde ise olduğu azalma yönündedir. Programın uzun vadeli etkileri incelendiğinde ise, programa katılan tüm çocukların reddetmeyi daha fazla uygun buldukları ve daha küçük çocukların ise daha az sosyal kaygı gösterdikleri gözlenmiştir. Programın istenmeyen bir yan etkisi olarak, en büyük çocukların güvenli de olsa dokunulma konusunda rahatsızlık hislerinin arttığ1 tespit edilmiştir. Programa katılımın okul ve sınıf ortamına etkileri de incelenmiş fakat çocukların sınıf arkadaşları ve öğretmen ile ilişkilerinin etkilenmediği belirlenmiştir. (Taal ve Edelaar, 1997). A.B.D'nin Tennessee bölgesindeki 14 devlet okulundan farklı etnik kökenden 1 ila 6. sınıflarda 1.177 öğrenci ile gerçekleştirilen bir diğer araştırma ise okul temelli bir çocukluk dönemi cinsel istismar eğitimi ve önleme programı olan dört oturumluk okul temelli "Nihayet Güvende" (Safe@Last) programının toplumsal düzeydeki göstergelerle ne ölçüde ilişkili olduğunu ortaya koymayı hedeflemiştir (Morris vd., 2016). Bu amaç doğrultusunda kişi başına düşen gelir ve kanıtlanmış istismar ve ihmal vakalarının oranı toplumsal düzeydeki temel iki gösterge olarak belirlenmiştir ve toplumsal düzeydeki göstergelerin programın etkililiği üzerinde belirleyici etkilerinin olduğu tespit edilmiştir. Müdahalenin etkileri, yüksek gelirli ilçelere kıyasla daha düşük gelirli bölgelerde yaşayan gençler için ve daha yüksek istismar/ihmal oranlarına kıyasla daha düşük oranların olduğu ilçelerde okullara devam eden gençler için daha güçlü bulunmuştur. Çocukların bireysel özellikleri ise (cinsiyet, 1rk) müdahalenin etkilerini azaltmamaktadır (Morris vd., 2016). 
Ülkemizde ise doğrudan kötü muameleyi önlemeye yönelik okullarda yürütülen merkezi bir faaliyet saptanamamıştır. İlköğretim kurumlarında yürütülen programlar incelendiğinde; rehberlik ve kariyer planlama dersi kapsamında ve ilköğretim kurumlarında rehberlik ve yönlendirme dersi programında ise ergenlik dönemindeki çocukların kendini tanıma/kabul, aile ve toplum ve kişiler arası ilişkiler yeterlik alanlarındaki bazı kazanımlara (ör. "Sahip olduğu haklarını belirtir.", "Fiziksel, sözel ve duygusal şiddetle karşılaştı̆̆ında nereden yardım alabileceğini belirtir.") yer verildiği (T.C. Milli Eğitim Bakanlığı [MEB], 2019) görülmektedir. Bu kazanımlar kötü muamelenin önlenmesi için okul temelli bilgilendirme kapsamında ele alınabilir. Öğretmenlerin çocuk haklarına yönelik bilgilendirmelerinde genel olarak ders konusu anlatma ve soru sorma gibi geleneksel yolları kullandıkları, dolayısıyla çocuklara aktarılan bilginin ders kitapları ile sınırlı olduğu bulgusu (Ersoy, 2012) ülkemizde ulaşılan bulgular arasındadır.

\section{İkinci temel unsur: Kötü muameleyi sonlandırmak için sırlara veda etmek}

Kötü muamelenin önlenemediği durumda, suçtan zarar gören çocuk için kapsamlı bir psikososyal destek hizmetinin süratle devreye girmesi gerekir (Reading vd., 2009; Öztürk, 2020). Psiko-sosyal destek hizmetinin yürütülmesi için ise öncelikle çocuğa kötü muamelenin saptanması gereklidir. Sırlara veda etmek; suçun bildirimini sağlamada ve kötü muamelenin kuşaklar arası geçişini önlemede rol oynar. Bu iki etkisi ile sırlara veda, kötü muameleyi durduran kilit bir unsurdur. İstismar veya ihmalin bildirilmemesi; aile içinde kalması ya da çocuğun yaşadığı durumu aile üyeleri dâhil hiç kimseyle paylaşmaması kötü muamelenin tekrarlanmasına yol açar (Tat ve Öztürk, 2019). Çocuğun kendini açma davranışı, kötü muamale gördüğünü üçüncü bir şahsa kendiliğinden veya bir yetişkinin uygun yöntemlerle gerçekleştirdiği mülakat yoluyla bildirimi ile gerçekleşir (Collin-Vézina, Sablonniére-Griffin, Palmer ve Milne, 2015). Kendini açma davranışı kötü muamelenin sona ermesini sağlayan adli süreci başlatan bir dönüm noktasıdır.

Çocuk adalet sisteminin ilk basamağını oluşturan Çocuk Şube Müdürlükleri, suç işleyen, suça yönelen ve suçun mağduru olan çocuklar için çalışmaktadır. Bu noktada hizmet veren çocuk polislerinin kötü muamele gören çocukların kendilerini açmaları konusunda destekçi olması, çocuklarla etkili ve doğru iletişim kurması beklenir. Ülkemizde 2019 yılı istatistiklerine göre, bir olaya karışarak güvenlik birimlerine gelen veya getirilen çocukların sayısı 511 bin 247'dir. Güvenlik birimlerine başvuran veya getirilen çocukların \%46,1'lik bir oranı (235 bin 931 çocuk) mağdur ve bu grubun \%87,5'i ise suç mağdurudur. Çocuk mağdur ile ilişkili suçun mahiyetini ise, yaralama, cinsel suçlar, aile düzenine karşı suçlar, tehdit, kişiyi hürriyetinden yoksun kılma ve hırsızlık oluşturmaktadır (TÜİK, 2020). Güvenlik sağlayıcıları, türlü sebepten dolayı güvenlik birimlerinde karşılaştıkları ve çocuk hakları bağlamında korunması gereken çocuklarla etkileşimlerinde yetişkinler için yararlandıklarından farklı bir yaklaşım benimser.

Ülkemizde 5395 sayılı Çocuk Koruma Kanunu'na göre polisin yanı sıra psikolog, diş hekimi, tıp hekimi, hemşire gibi sağlı alanı çalışanları ile öğretmen ve sosyal hizmet verenler çocuk istismar ve ihmali şüphesinde bile, bildirim yükümlülüğü bulunan meslek gruplarıdır (Çocuk Koruma Kanunu, 2005). Çocuk ile iletişim kurmada uzmanlaşmış veya uzmanlaşmamış olan bu profesyonellerin, özellikle mağduriyet durumunda çocukların gelişimsel özellikleri, ihtiyaç ve sorunları hakkında temel düzeyde bilgi sahibi olması beklenir. Emniyet Genel Müdürlügü̈'nde oluşturulan çocuk birimlerinde ise iletişimde uzmanlaşmış ve çocuk gelişimine hâkim olmaya dayalı bu yaklaşımın benimsenmesi, bugünün çocukluk kavrayışında önemli bir gelişmedir. Karataş, Aslan ve Kılıç (2019) Türkiye'de çocuk polisinin yapılanması ve görevleri kapsamında 
sosyal hizmet sistemini ele aldıkları çalışmalarında, Çocuk Şube Müdürlüklerinden beklenen düzeyde destek hizmetini engelleyen bir dizi durum tespit etmiştir. Çocuk Şube Müdürlüklerindeki polislerin formasyon eksikleri, çocuk alanındaki tecrübesizlikleri ve ek olarak yasal düzenlemelerin nihai sonuca ulaşmaması sosyal hizmet çalışanlarının çocuklara yönelik koruyucu, destekleyici, rehabilite edici, güçlendirici bir dizi mesleki rolleri yerine getirmede yaşanan sorunlar ile ilişkilendirilmiştir. $\mathrm{Bu}$ engellerin giderilmesinin yolu olarak ise, diğer kurumlarla işbirliği yapmak ve koordinasyon içinde çalışmak önerilmektedir (Karataş vd., 2019).

Uluslararası ve ulusal emniyet birimlerinin koordine bir şekilde çalışarak durdurmada başarıya ulaştığı bir istismar türü, çevrimiçi çocuk istismarıdır. Gelişen teknolojiyle beraber sanal ortamların kullanımı çocuklar arasında da artmakta, çevrimiçi ortam uluslararası hukukta çocuk istismarı vakalarında artışa neden olan ciddi bir çocuk hakları tehdidi olarak görülmektedir (Altobelli, 2010). Çevrimiçi ortamda gerçekleşen 4 istismar vakasını inceleyen bir çalışmada, ulaşılan istismar vakalarının hiçbirinde emniyet güçlerine bildirim yapılmadığ çıkarılmıştır (Çalışkan, 2019). Çocuk mağdurların bildirimde bulunmaması, vakalarda ivedilikle eyleme geçilmesini ve faillerin tutuklanmasını engelleyen bir durum olarak görülmektedir. İstismar şüphesinde gecikmeksizin bütün bilgilerin emniyet güçleriyle paylaşılması istismarın tekrarını durdurabilir. Çocuğun kendini açmasının önemi kadar, ailenin de çocuğunun davranışlarını, alışkanlıklarını gözlemesi, internet kullanımını takip etmesi bu vakaların ortaya çıarılmasında önemli bir etkendir. Bununla birlikte, bir diğer istismar türü olan aile içi cinsel istismar vakalarında aile failleri gizleyebilmekte/koruyabilmekte veya çocuğa inanmayarak (Kopiec, Finkelhor ve Wolak, 2004) veya durumu bildiği halde emniyet güçlerine bildirim yapmayarak (Çalışkan, 2019) istismarın ortaya çıkmasını geciktirmekte ve emniyet güçlerinin faillere ulaşmasını engellemektedir.

Mağdur olan çocuğun ve/ veya aile üyelerinin suçu geç bildirmesi, bildirimde bulunmaması veya gizlemesinin altında yatan en temel etken olarak toplumsal çekinceler gösterilmektedir. Bildirimi etkileyen toplumsal çekinceler, kötü muameleye uğrayan çocuğu acil ruh sağllğı hizmetinden mahrum birakmakta ve müdahaleyi geciktirmektedir (Kopiec vd., 2004). Çekincelerin kaynağ1, "popoya şaplak", "vücuda terlik" gibi toplumda yaygın kullanılabilen bazı eylemlerin bir fiziksel istismar mı yoksa kültüre has ve "çocuğa zarar vermeyen" bir geleneksel disiplin yöntemi mi olarak görülmesine dair tartışmalar ile de ilgili olabilmektedir (Choi, Kim, Kim ve Park, 2013). Çocuğun ve destekçi aile üyelerinin polisin konuyu ciddiyetle ele alacağına dair olumsuz inançları ve tehdidin halen sürmesi (Finkelhor vd., 2001) ise yine toplumsal çekincelere birer örnek olarak gösterilmektedir.

Çocuklara kötü muameleyi genellikle onlara ulaşabilen, yakınlarındaki yetişkinler uygular (Bartlett, Kotake, Fauth ve Easterbrooks, 2017; Pears ve Capaldi, 2001; Stouthamer-Loeber, Loeber, Homish ve Wei., 2001; Tracy, Salo ve Appleton, 2018; WHO, 2002). Bu durum kötü muamelenin ailedeki kuşaklar arası geçişini ve aile iliş̧kilerini anlamayı gerekli kılar. Geniş bir ekolojik perspektiften baktığımızda, ailenin düşük sosyo-ekonomik düzeyden olması kötü muamele için temel bir risk unsuru olarak belirtilir. Her kültürde benzer biçimde, yoksullukla bağlantılı bir diğer risk etkeni ise çocuğun olumsuz davranışlarını durdurmasını umarak kat1/zorlayıc1 (coercive) ebeveynlik uygulamaktır (Conger, Ge, Elder, Lorenz ve Simons, 1994; Teng, Kuo ve Zhou, 2018). Duygusal istismar türünden kötü muameleyi ise çocuğu disipline etmenin yaşamının erken döneminden itibaren ergenliğe değin etkili bir yolu olduğunu düşünen düşük eğitim düzeyinden babaların, annelere göre daha fazla kullandıkları (Sofuoğlu, Sarıyer ve Ataman, 2016) bildirilmektedir. Cocuklara dayak, cinsel istismar türünden kötü muamelede 
bulunan yetişkinlerin, kendi çocukluklarında da kötü muamele gördüklerine dair klinik temelli öz-bildirimleri mevcuttur. Ebeveynlerden özellikle annenin çocukluğunda yaşadığı ihmal ve çoklu istismar yaşantılarının kötü muamelenin sonraki kuşaklara aktarılma olasılığını artırabileceğine dair bulgular mevcuttur (Bartlett vd., 2017; Pears ve Capaldi, 2001). Buna karşın, fail olma durumunda cinsiyete bağlı farkların karışık olduğu; örneğin adli psikoterapi alanında uzmanlaşmış bir merkeze devam eden 843 yetişkinin yer aldığı bir çalışmada erkek faillerin fail olmayanlara göre 3 kat $(\% 35 ; \% 11)$ daha fazla oranda çocukluk dönemi cinsel istismara uğradıklarını, kadınların ise çocukluk dönemi öykülerinde erkeklere göre daha yüksek (\%43) cinsel istismar bildirdikleri halde 96 kadın katılımcıdan sadece birinin fail olduğu tespit edilmiştir (Glasser vd., 2001). Bu bulgulardan hareketle, kötü muamelenin kuşaklar arasındaki geçişinden sorumlunun sadece babanın eğitimsizliği veya annenin çocukluk travmaları olduğu fikrine kapılmak yanlı olacaktır. Aksine, Lange ve diğerleri (2019) 166 nicel ve 108 nitel çalışmayı bir arada değerlendirdikleri sistematik derleme çalı̧̧malarının sonucunda, çocukluğunda istismara uğramış olan annelerin çocukları cinsel istismarı kendilerine açtığında yüksek duygusal stres gösterdiklerini, çocuklarını "istismar edebilecekleri düşüncesinden" korktuklarını ve kendilerini aşırı koruyucu olarak algılayabildiklerini göstermektedir. Aynı çalışmada, istismar öyküsü olan annelerin, çocuklarına inanıp inanmama noktasında ve çocuklarına fiziksel ceza yoluna başvurma düzeylerinde istismara uğramamış annelerden farklılaşmadıkları da saptanmıştır (Lange, Condon ve Gardner, 2019). Çocukluk dönemlerinde yüksek düzeyde istismara maruz kalmış ebeveynlerde bile tutarlı ebeveynlik ve düşük çocuk istismarı bildirilmektedir (Pears ve Capaldi, 2001).

Çocuğa kötü muamelenin kuşaklar arası geçişini, eşler arasındaki iliş̧kiler üzerine odaklanarak anlamak da mümkün görünmektedir. Buna göre, Visser ve diğerlerinin (2016) çocuklukta travma bağlantılı belirtilerin ebeveynin psikopatolojisi ile değil de eşler arasındaki şiddet ile açıklanabildiğine dair bulguları, ailedeki şiddetin izlerinin dolaylı etkiler yoluyla bir sonraki kuşakta da gözlenebileceğinin bir kanıtıdır (Visser, Schoemaker, de Schipper, Lamers-Winkelman ve Finkenauer., 2016). Ailede içi şiddet ve ebeveynler arasındaki her türden yıkıcı ilişki, bu ailede gelişen çocukların yaşamlarını oldukça erken dönemden itibaren olumsuz biçimde etkilemektedir (Lewis ve Feiring, 1992). Çatışmalı, işlevsiz veya sorunlu bir ailede büyümek; eşlerin ebeveynlik konusunda çatışmalarına ve çocuğa olumsuz ebeveynlik sergilemelerine yol açarak da ailenin genç kuşaklarına zarar verebilmektedir (Öztürk, 2018). Çocuk büyüdüğünde ise, ebeveynlerinin oluşturduğu olumsuz modelleri kendi yetişkin yakın ilişki dinamiklerindeki sorunların çözümü için birer norm olarak kabul edeceği, kurduğu ailedeki ilişkilerinde de şiddete başvuracağ 1 ve hatta sergilenen şiddet karşısında çaresiz hissedeceği (Rothenberg, Hussong ve Chassin, 2016) öngörülmektedir.

Son yıllarda düzenlenen kapsayıcı çalışmalar, kötü muamelenin olumsuz etkilerinin kuşaklar aras1 geçişinin kader olmayabileceğini göstermektedir. Lachman ve diğerlerinin (2017) Güney Afrika, Cape Town'da yaşayan ve 3-8 yaşlarında çocuğu olan düşük gelirli 68 ebeveynin katılımı ile kötü muameleyi önlemede ebeveyn eğitiminin hedeflendiği "Küçük Çocuklar için Sinovuyo İlgili Aileler Programı" nın etkilerini sınadıkları çalışmaları bu duruma örnek verilebilir. Ne bağımsız gözlemcilerin ne de ebeveynlerin öz bildirimlerine gore, grup temelli bu programa dahil edilen ebeveynlerin çocuklarına uyguladıkları katı (ihmalkar ve istismarcı) ebeveynliğin sıklığında herhangi bir azalma sağlanamamıştır. Bu olumsuz sonuçlara karşın bağımsız gözlemciler, programa katılan ebeveynlerin bekleme listesindeki ebeveynlere göre program sonunda çocukları ile daha fazla oyun oynamaya başladıklarını, ebeveynliklerinde daha sık olumlu sözel geri-bildirimleri kullandıklarını ve çocuklarında ise olumlu sosyal davranışların 
anlamlı olarak daha fazla gözlendiğini bildirmiştir. Araştırmacılar bulgularını, programın zayıf kaldığı yönleri olarak belirledikleri ebeveynlerin olumsuz çocuk davranışı yönetimi ve şiddet içermeyen disiplin stratejilerinin öğretimi ile ilgili bileşenlerinin güçlendirilmesi fikri üzerinden ele almıştır. Bize göre bu sonuçlar, kuşaklar arası olumlu ve yakın ilişkileri ilerletme unsurunun eklenmesinin müdahale programının etkililiğini artırma potansiyeline işaret etmektedir. Çocuğa kötü muamelenin saptandığ 1 ailelerde aileye işlevsellik kazandırmaya yönelik yapılan müdahale çalışmaları ile; ebeveynin çocukla birlikte oyun oynama davranışının sıklığında artış (Lachman vd., 2017), tutarsız ebeveyn disiplininde azalma ve olumlu ebeveynlikte artı̧s (Cluver vd., 2016; Shenderovic, Cluver, Eisner ve Murray, 2020) ile adli kayıtlardan takip edilen kötü muamelenin tekrarlanma oranında düşüş (Lachman vd., 2020; Lee vd., 2018) sağlanabilmektedir. İstismarın farklı türlerinin üç kuşak boyunca aktarımının değerlendirildiği boylamsal bir çalışmada ise, şiddetin nesiller boyu geçişinin ebeveyn-çocuk arasındaki "destekleyici ilişki" yoluyla önlenebilmesinin mümkün olduğu ortaya konmuştur (Tracy vd., 2018). Aile içi kötü muamelenin kuşaklar arası aktarım riski destekleyici ebeveynliğin ve aile içi açık iletişimin artırılması sayesinde azaltılabilmektedir (Bartlett vd., 2017; Pears ve Capaldi, 2001; Tracy vd., 2018).

\section{Üçüncü temel unsur: Psiko-sosyal müdahale hizmetleri ile endișeleri azaltmak}

Nitelikli müdahale için her çocuğun durumu, gelişimi, çevresi ve geçmişi birlikte ele alınır (Belsky, 1980) ve doğru tanımlanır (Stoltenborgh, Bakermans-Kranenburg, Lenneke ve van Ijzendoorn, 2012). Daha küçük yaştaki çocukların henüz olgunlaşmamış baş etme becerileri, o grubu istismar ve ihmalin olumsuz sonuçları karşısında incinebilir kılmakta, buna karşın azımsanmayacak sayıda çocuk sahip oldukları bir takım bireysel ve sosyal kaynaklar sayesinde bu süreçten dayanıklı biçimde çıkabilmektedir. Kötü muameleye rağmen, gelişimleri olumsuz etkilenmeyen bu dayanıklı çocuklar; bilişsel ve akademik başarıya, kendine ve diğerlerine dair olumlu algılara sahip olma gibi bireysel özelliklerin yanı sıra sıcak ve destekleyici yakın sosyal çevreye sahip olmaları açısından ortaklaşırlar (Margolin ve Gordis, 2004).

Her çocuk dayanıklı değildir ve kötü muamelenin olumsuz etkilerinden çocuğu korumak için, travmatik yaşantıyı mevcut bağlamında derinlemesine anlamak kritiktir. Kötü muameleye maruz kalan çocuklar sıklıkla aynı anda birden fazla kötü muamele biçimi ile karşılaşmaktadır (ör. Arata, Langhinrichsen-Rohling, Bowers ve O'Brien, 2007; Berzenski ve Yates, 2011). Örneğin, okul çağında cinsel istismara uğramış çocukların \%25 ila \%75'i fiziksel ve duygusal kötü muamele biçiminden en azından birine daha maruz kalmaktadır (Hébert, Langevin ve Oussaïd, 2018). Berzenski ve Yates (2011)'in çocukluk çağında farklı türlerdeki kötü muamelenin davranış sorunlarına etkilerini geç ergenlik dönemindeki 2637 bireyde araştırdıkları çalışmaları bu noktada aydınlatıcıdır. Kümeleme analizi sonuçları; çocukluklarında duygusal türden kötü muamele gören gençlerde kaygı ve depresyon sorunlarının, fiziksel ve duygusal kötü muamelenin bir arada görüldüğü gençlerde ise maddenin kötüye kullanımı ve riskli cinsel ilişki gibi davranış sorunlarının ortaya çıktığını göstermiştir (Berzenski ve Yates, 2011). Kötü muamelenin çocuğun ruh sağlığı sorunları üzerinde birikimli etkisinin olduğu ve türlerine göre farklı nitelikteki psikolojik sorunlar ile ilişkili olabileceği görülmektedir.

Kötü muamele gören çocukta gelişebilecek psiko-sosyal sorunlara dair endişeleri azaltmanın önemli bir yolu ise, genel popülasyondan çocukları klinik açıdan düzenli olarak taramak, çocuğun maruziyetini erken dönemde saptamak ve erken müdahale etmektir. Klinik çalışmalar, çocukluk döneminde kötü muamele gören bireylerde endişe/kayg1 ve korku türünden yoğun olumsuz duygulara eşlik eden psikolojik sorunların varlığına işaret eder. Bu psikolojik sorunların 
kaynağı olarak, çocuğun kötü muamele geçmişi veya aile öyküsü gösterilmektedir. Duygularımızı toplumsal bir takım norm ve beklentilere göre sergilememizi sağlayan duygu yönetimi becerilerindeki olgunlaşma, çocukluk döneminde görülmeye başlar ve genç yetişkinliğe değin gelişimini sürdürür (Goodman vd., 2016). Evde kötü muamele ile büyümek, çocuğun evde sergilenen duyguları sağlıklı biçimde kavramasını ve duygu düzenleme becerisinin sağlıklı gelişimini engelleyen riskler barındırır. Erken yaştan itibaren kötü muamelenin olduğu sağlıksız evlerdeki çocuklar daha çok olumsuz ve daha az olumlu duygular izleyerek büyür ve sergiledikleri duygular da ebeveyn tarafından olumsuz biçimde değerlendirilir (Francis ve Wolfe, 2008). Kötü muamele görerek büyüyen çocuğun kendinden beklenenleri anlaması ve duygusal bilgiyi işlemlemesi için gerekli olan bilişsel kapasitesi de azalır. Bu nedenledir ki istismar edilen çocuklar, öfke gibi olumsuz duygulara duyarlıdır ve olumsuz duyguları diğer çocuklardan çok daha çabuk algılarlar (Young ve Widom, 2014, s. 1370). Duygular, bellekte kodlanmış anılara eşlik eden psikolojik etkenler olmaları nedeniyle, kötü muamele türünden bir travmatik olayın kodlanması, hatırlanması ve anlamlandırılmasında da rol alırlar (Goodman vd., 2016) ve travma kaynaklı olumsuz duygular bireyde örtük veya açı bir dizi gelişimsel soruna yol açma potansiyeli taşırlar (Öztürk, 2020).

Kötü muamele sadece duygusal bilginin kodlanması ve hatırlanması sürecini bozmaz, psikolojik işlev sorunlarına da yol açar. Sosyal kaygı ev içi şiddet, olumsuz ebeveynlik stilleri, cinsel istismar gibi çocukluk dönemi travmalarıyla ilişkili duygu temelli bir psikolojik işlev sorunudur ve yaygın etkisi ile tanınır (Bandelow vd., 2004; Simon vd., 2009). Sosyal kaygı bozukluğu tanılı gruplar $(\% 88)$ sağlıklı yetişkinlerin $(\% 47.5)$ nerede ise iki katı oranında travmatik çocukluk deneyimleri bildirmekte (Bandelow vd., 2004) ve bildirilen çocukluk çağı travma türleri arttıkça sosyal kaygı puanları da yükselmektedir (Simon vd., 2009). Çocukluk döneminde klinik olarak tanılanmayan ve müdahale edilmeyen sosyal kaygı, yetişkinlikte sıklıkla majör depresyon, maddenin kötüye kullanımı ve diğer kaygı bozuklukları (Kuo, Goldin, Werner, Heimberg ve Gross, 2011, s. 468-469) gibi geniş bir grup klinik sorunun eşlikçisidir. Kaygı sorunlarına erken dönemde uygulanan psikolojik müdahale, çocuğun sağlıklı gelişiminin sekteye uğramasını engeller.

Kötü muamele ile sosyal kaygı arasındaki ilişkinin klinik açıdan oldukça az incelenen bir yönü ise, sosyal kaygının çocuğun akranlarınca istismar edilme riski oluşturmasıdır. Buna göre, çocuklukta sosyal açıdan çekingen ve kaygısı yüksek olanlar olmayanlara göre ergenliklerine değin zorbalığa daha fazla maruz kalabilmektedir (Rubin, Coplan ve Bowker, 2009, s. 152). Sosyal kaygıyı azaltmaya yönelik bilişsel-davranış̧̧ı yöntemle ülkemizde oluşturulan okul temelli etkili psiko-eğitim programlarıyla (Aydın, Tekinsav-Sütçü ve Sorias, 2010; Nedim-Bal ve Öner, 2014; Sertelin Mercan ve Yavuzer, 2017) ergenlerde sosyal kaygının azaltılabileceği gösterilmiştir. Endişelerin giderilmesinde erken klinik müdahalenin yanı sıra, sosyal destek ve çocuğa sağlanan güvenlik hissi kıymetlidir. Zorbalıkla mücadele programları; ergen ve ebeveyn depresyonunda önemli ölçüde azalma, algılanan ebeveyn desteğinde artış, ebeveynlerin stres düzeyinde ve maddeyi kötü kullanımında azalma ve sosyal destek algılarında artışı (Cluver vd., 2016) sağlayarak kaygıyı ebeveyn ve çocuk için azaltmaktadır. Lam ve diğerleri (2018) 5-9 yaşları arasındaki çocukları Sri Lanka'nın yedi ayrı bölgesinde yürütülen BeSafe eğitim programına katılan 835 ebeveynden programın niteliklerine ve çocukları için etkililiğine dair algılarından yararlanmıştır. Sonuçlar, "programının etkinliği hakkında olumlu tutumlara sahip ebeveynlerin, çocuklarının okulda güvende olduğuna dair inançlarının da güçlü olduğunu 
göstermektedir. Çocukların kötü muameleye dair okulda konuşabilecekleri birilerinin olduğunun bilinmesi ise, okulda güvende oldukları duygusunu geliştirmektedir. (Lam vd., 2018).

Yüksek standartları olan bir psikolojik müdahale uygularken, çocuğu "kötü muamele mağduru" olarak tektipleştirmekten imtina ederek ilerlemek esastır. İstismar ve ihmal yaşantılarına nitelikli müdahalede önemli bir diğer ölçüt ise gelişimsel kavrayıştır (Yates, 2007) ve farklı yaşam dönemlerine özel müdahale yöntemleri geliştirmekle ilişkilidir. Okul öncesi dönemde kötü muameleye müdahalede yararlanılan iki yaklaşım olan "Dayanıklı Akran Müdahalesi” (Resilient Peer Treatment) ile "Dikkat Kontrolü”nün (Attention Control) çocuklardaki olumlu psikolojik sonuçları açısından birbiri ile karşılaştırıldığı bir çalışmanın sonuçları gelişimsel kavrayışı örneklemek için önemlidir (Fantuzzo, Manz, Atkins ve Meyers, 2005). Gelişimsel-ekolojik bir modele dayanan ve oyun ve akran aracılı bir kötü muamele müdahalesi olan "Dayanıklı Akran Müdahalesi" (DAM); doğal bir oyun alanında sosyal yönden yetkin bir akran ile ve oyunlarda destekleyici rolü olan ebeveynlerin yer aldığı bir koşulda uygulanır. "Dikkat Kontrolü” koşulunda ise; ilk yaklaşımdaki oyun koşulları aynı olmakla beraber, bir oyun arkadaşı bulunmaz ve destekleyici ebeveyn etkin oyun için cesaretlendirmeksizin oyunları gözetir. Dezavantajlı koşullardaki ailelerin çocuklarının yer aldığı Head- Start erken çocukluk eğitimi programına katılan 46 çocuğa uygulanan DAM'i takiben; çocuklarda hem program tamamlandığında hem de takip eden 2. ayda olumlu ilerlemeler gözlenmiştir. Fiziksel istismar, fiziksel ihmal ve ikisinin birlikte gözlendiği bir grup ile gözlenmediği bir diğer grup "içekapanık" çocuğun katılımıyla gerçekleştirilen bu çalışmada; müdahale sonrası tüm çocuklarda olumlu sonuçlar elde edilmiştir. Okul öncesi dönemdeki bu çocukların akranlarıyla daha fazla etkin oyun oynadığı ve bu koşula atanmadan önce sadece kendi başına oyun oynayan çocuklarda ise anlamlı olarak tek başına oyunun azaldığı yönünde bulgular elde edilmiştir. Aynı araştırmada problem davranış ile ilgili ölçümler ele alındığında, araştırmacıların öncül çalışmalarında ulaştıkları bulguları tekrarlar biçimde, DAM grubundaki çocukların diğer gruba göre daha az içselleştirme ve dişsallaştırma problemi gösterdikleri görülmüş ve okulöncesi dönemde kötü muameleye müdahale için oyun yöntemi önerilmiştir (Fantuzzo vd., 1996; Fantuzzo vd., 2005). Daha büyük çocuklar ve gençlerde ise; ailenin psikolojik müdahaleye katılımının (Cluver vd., 2016) ve arkadaş desteği, çocuğun yönderlik yapılan kulüpler, spor kulübü, akademik topluluklar gibi daha farklı sosyosportif ve kültürel etkinliklere katılımının desteklenmesinin (Dion vd., 2016; Kwak, MihalecAdkins, Mishra ve Christ, 2018; Thomas ve Zimmer-Gembeck, 2012) psiko-sosyal müdahalede yer verilmesinin olumlu etkilerine yönelik bulgulara ulaşılmıştır. Örneğin Dion ve diğerleri (2016), akran desteğinin rolünü kötü muamelenin farklı biçimlerine (ör. Cinsel istismar, fiziksel istismar ve eş şiddetine maruz kalma) ve çoklu kötü muameleye maruz kalma ile psikolojik sorunlar arasındaki birikimli ve linear ilişki içinde incelemiştir. Genel ergen evrenini temsil eden 605 ergenin verisi üzerinden elde edilen bulgular, gençlerin 14 yaşındayken arkadaşlarından daha yüksek akran desteği algılamasının, 14 yaşından önce yaşadıkları kötü muamelenin olumsuz etkisinin ötesinde bir etkiye sahip olduğunu; akran desteğinin bu gençlerin 14-24 yaşları arasında daha düşük düzeyde psikolojik sorun yaşamalarında etkili olduğunu göstermiştir (Dion vd., 2016). Kwak ve diğerleri (2018) ise, A.B.D.'de Çocuk Koruma Hizmeti (CPS) tarafından kötü muamele riski altında oldukları tespit edilen 790 ergenin katıldığı araştırmalarında, ergenlere yönelik çeşitli türde organize faaliyetlerin akademik ve sosyo-duygusal gelişime etkilerinin sınamıştır. Araştırmanın sonucunda, sosyal ve kültürel faaliyetlerin kötü muamale riski altındaki ergenlerin olumlu gelişimlerine etkisinin dört temel yol üzerinden gerçekleştiği saptanmıştır. Buna göre ergenlerin 1) daha yüksek düzeyde okula bağlılığının yönderlik yapılan gruplara, spor kulüplerine ve akademik kulüplere katılımı ile; 2) daha az depresif belirtinin akademik kulüplere katılım ile 
pozitif yönde ilişkiliyken; 3) sanat ve müzik kulüplerine katılan ergenlerde, katılmayanlara göre daha fazla travma belirtisi bildirildiği ve 4) yönderlik yapılan gruplara katılımın suçluluk ve travma semptomları üzerindeki etkilerinin ise maruz kaldıkları kötü muamele türüne göre farkl1lık gösterdiği ortaya konmuştur (Kwak ve diğerleri, 2018). Düzenledikleri çalışma ile Thomas ve Zimmer-Gembeck (2012), 12 oturumluk standart "Ebeveyn-Çocuk Etkileşimi Terapisi” nin etkinliğini risk altındaki veya kötü muamele öyküsü olan 151 Avustralyalı ailede sınamıştır. Riskli gruplarla düzenlenen diğer bazı çalışmaların aksine, bu çalışmada terapi protokolünde veya sürecinde gruba özel herhangi bir uyarlama yapılmamıştır. Terapi grubundaki 3-5 yaşındaki çocukların anneleri, bekleme listesindekilere ve terapi öncesi temel düzeydeki annelere kıyasla stres düzeylerinde ve çocuklarının içselleştirme ve dışsallaştırma davranışlarında azalma bildirmiştir. Klinik ortamda gözlenen çocuk-ebeveyn etkileşimlerinde ise, annelerin övgü, betimleme ve yansitma türünden olumlu sözel ifadelerinin ve duyarlı ebeveynlik düzeylerinin arttığ 1 saptanmıştır. Elde edilen bu bulgular, bu terapinin çocuk koruma sistyemine kayıtlı ve kötü muamale açısından yüksek riskli gruplara uyarlanmış uzun versiyonları ile bu çalışmada uygulanan standart versiyonunun etkililiğinin benzer olduğunu da göstermesi açısından değerli bulunmuştur.

\section{Dördüncü temel unsur: Kötü muameleye uğrayan çocuğa toplumsal destek sağlamak}

Ülkemizde 5395 sayılı Çocuk Koruma Kanunu'na sağlık, eğitim, güvenlik ve sosyal hizmetler alanından bir grup mesleki uygulamacı, çocuk istismar ve ihmali şüphesinde bile bildirme yükümlülükleri bulunmaktadır (Çocuk Koruma Kanunu, 2005). Mesleki uygulamacıların çocuğa kötü muameleyi bildirme hükümlülüğü ile çatışan "kültürel” ve "toplumsal” durumlarla karşı karşıya kalmaları ve bilgi eksiklikleri çocuğa kötü muame alanında verilen koruma ve destek hizmetinin sekteye uğraması riskini barındırır. Toplumsal desteğin az olduğu durumlarda çocukla çalışan meslek gruplarının deneyimleri ve bilgileri, çocuğu kötü muameleye karşı korumak ve kötü muamelenin psikolojik etkilerini önlemek konusunda en etkin unsurdur. Buna karşın, profesyonellerin saha deneyimlerinden yararlanan bilimsel çalışmaların ve kötü muamele alanında erişebilecekleri kaynakların sınırlı olduğu gözlenmektedir. Oppenheim-Weller ve Zeira (2018), uluslararası kanıta dayalı ve riski altındaki 5 yaş ve daha küçük çocukların ailelerine ev ziyareti temelli bir kötü muameleye müdahale programı olan "Güvenli Bakım" in (SafeCare) farklı bir kültür için (İsrail) uygulanması sürecinde karşılaşılan zorlukları annelerin yanı sıra profesyonellerden oluşan bir grupta ele alınmıştır. İsrailli 5 anne ve 3 sosyal çalışmacı ile yürütülen ayrıntılı görüşmeler, müdahale programının etkili olduğunu ve özellikle programın ev ziyaretleri bileşeninin ve ev ziyaretleri esnasında sosyal-çalışmacılar ve aile bireyleri arasında kurulan ilişkilerin görüşülen paydaşlar tarafından takdir edildiğini göstermişstir. Programın hem işlemsel hem de içeriksel yönlerine illişkin pek çok iyileştirici öneri ortaya konmuş, bu öneriler: kullanılan dil/ terminoloji, programa katılım koşulları ve işlemleri, programa katılımcıların dâhil olmasını sağlayacak teknikler ve programın etkiliğini değerlendirmenin yolları başlıkları /temaları altında toplanmıştır (Oppenheim-Weller ve Zeira, 2018). Kötü muameleye müdahale ve eğitim çalışmalarıyla ilgili alanyazın tarandığında, çoğunlukla bu hizmetlerin ebeveynlere yönelik olduğu (Cluver vd., 2016; Turner, Robbins, Rowlands ve Weaver, 2017; Shenderovich vd., 2020) ve ebeveyni ve çocuğu beraber ele alan az sayıda (Cluver vd., 2018) ve çocuklarla sahada çalışan meslek elemanlarına (hemşirelere) yönelik kısıtlı sayıda çalışma (Lee ve Chou, 2016) düzenlendiği tespit edilmiştir. Çocuğun kötü muameleye uğramasına dair sunulan müdahale programlarının verimliliğinin ve hizmet sağlayıcı meslek gruplarının etkililiğinin tespiti ve takibine yönelik bilimsel çalışmaların, erişilebilir toplumsal hizmetlerin sunulması 
kadar değerli olduğu düşünülmektedir. Lee ve Chou (2016) tarafindan düzenlenen deneysel bir çalışmada çocuk kliniklerinde çalışan Taiwan'lı hemşirenin ihtiyaçlarının tespit edilerek geliştirilen "Hemşireler için Çocuk İstismarı ve İhmali Eğitim Programı" nın hemşirelerin çocuğa kötü muameleyi bildirme konusundaki özyeterlikleri üzerindeki etkisi incelenmiştir. Bulgular, programa katılan hemşirelerin ( $\mathrm{N}=40)$ katılmayanlarla $(\mathrm{N}=40)$ karşılaştırıldıklarında; hem uygulamanın son oturumunda hem de son oturumu takip eden 1 ay içinde, altı farklı öz yeterlik boyutunun altısında da kendilerini daha yeterli olarak bildirdiklerini ortaya koymuştur. Turner ve diğerleri (2017) ise, New York'ta çocuk koruma sistemine kayıtlı farklı etnik kökenden 3875 ailenin verilerini takip ederek, çocuğa kötü muameleyi azaltmak amacıyla uygulanan "İşlevsel Aile Terapisi- Çocuk Refahı" (İAT-ÇR) ile "Olağan Bakım" (OB) programlarının verimi ve etkililiğini karşılaştırmıştır. Bu çalışmada öncelikle iki farklı hizmet türünden yararlanan aileler, hizmet öncesindeki risk durumlarına göre hesaplanan bir tabakalı kötü muameleye yatkınlık puanlaması kullanılarak eşleştirmiş ve dosyalarındaki bilgiler 16 ay boyunca takip edilmiştir. Ailelerin çocuk koruma sistemine sevk edilme nedenleri arasında çocuk istismarı veya ihmali $(\% 57,4)$, dezavantajlı koşullarından dolayı çocuk destek hizmetine duyulan ihtiyaçları $(\% 56,9)$ veya çocuk sağlığ 1 ve güvenliğine yönelik diğer türden endişeler $(\% 42,8)$ bulunmaktadur. İki program karşılaştırıldığında, İAT-ÇR programının OB'ye gore daha fazla verimli ve etkin olduğu sonucuna varılmıştır. Bulgular, İAT-ÇR hizmet türündeki ailelerin müdahale sürecini daha hızlı tamamladıklarını, programa daha fazla bağlı kaldıklarını ve New York şehri Çocuk Hizmetleri Birimi'nce planlanan hizmet hedeflerinin (ör. müdahalenin gençler ve aileleri için toplam 7 ayda tamamlanması) tümünü karşılama olasılıklarının ise önemli ölçüde daha yüksek olduğunu göstermiştir. OB'ye katılan ailelere gore İAT-ÇR programına katılan daha yüksek risk faktörlerine sahip ailelerde ise takip eden süreçte, çocukların evleri dışındaki bir diğer yere (akraba, koruyucu aile, kurum) daha az oranda yerleştirildiği saptanmıştır. Toplumsal desteğin, hizmetin ve mesleki deneyimin yetersiz kaldığı durumlarda çocuğu koruyabilmek için ise; bireylerin çocuğa kötü muamelenin saptanması ve durdurulması için mesleki sorumlulukların ötesinde, insani ve vicdani sorumluluğu olan bir vatandaş olarak çocuğun yararına daha güçlü bir irade oluşturmasını gerektirir. Bir benlik gücü olan özyeterlik düzeyindeki artış, istismarda kendini açmayı destekleme ve adli şikâyeti başlatma ile ilişkilidir. Nitekim hemşireler ile yürütülen bir eğitim çalışması sonucunda, çocuk istismarı ve ihmali şüphesini bildirme konusundaki özyeterlik düzeylerinde artış bildirilmiştir (Lee ve Chou, 2016).

Nitelikli psiko-sosyal müdahale programlarının ve çocuğa kötü muamele üzerine kontrollü bilimsel çalışmaların en yaygın olduğu ülkelerden biri olan A.B.D.'de; sürecin hızlı tamamlandığı ve daha az terapi seansı gerektiren müdahalelerin daha fazla ailenin bu hizmete erişmesini kolaylaştırdığı bildirilmektedir. Sosyal-öğrenme yaklaşımına dayanan ve çocuk koruma sistemleri kapsamında ücretsiz sunulan bu müdahale hizmetlerinde başarının diğer önemli göstergeleri ise; dahil olan ailelerde tekrarlanan çocuğa kötü muamelenin azalması, düşük relaps oranı ve bir diğer klinik bölüme sevkin azlığı olarak belirlenmiştir (Turner vd., 2017). Çocuk koruma hizmeti sistemine dâhil olmak ve yanı sıra ev ziyaretlerinde verilen eğitimler, A.B.D.'li istismarcı annelerin çocuğa yeniden kötü muamelede bulunma riskini azaltmaktadır (Lee vd. 2018). Programın ailelerin yaşadıkları doğal ortamında gerçekleşmesi, ev ziyareti yapan uygulamacılarla ailenin kurduğu olumlu ilişkiler ise etkili bir ev ziyareti programın olumlu özellikleri olarak saptanmıştır (Oppenheim-Weller ve Zeira, 2018). Grup eğitimlerinde ise eğitimcilerin iyi niteliğe sahip sunumları ile ev ziyaretinde oluşan olumlu ortam aynı programda birleştiğinde; çocuğa kötü muamelede bulunan ebeveynlerin programa bağlılığında ve tutumlarında olumlu değişimler sağlanabilmektedir (Alvarez vd., 2016). Ebeveynleri ekonomik yönden güclendiren beceriler 
edindiren sosyal öğrenme temelli programlarının ise, özellikle asgari ekonomik güvencesi olan veya güvencesiz ülkelerde uygulanmasının, çocuklara yönelik şiddeti azaltmakta etkili olabileceği ileri sürülmektedir (Cluver vd., 2020). Doksanlı yılların başlarında A.B.D. toplumuna çocuğa kötü muamelenin psikolojik etkilerinin tedavisi ve sağlanan sosyal hizmetlerin maliyeti milyonlarca dolar olarak tahmin edilmiştir (akt. Cicchetti ve Olsen, 1990, s.270). Toplumlar çocuğu kötü muameleden koruma ve olumsuz etkilerine müdahale için erişilebilir hizmetler sağlayarak, ailelerin ve araştırmacıların beraber nitelikli müdahaleler programlaması ve takibi için kontrollü çalışmalar yayınlanmasına pratik ve mali destek sağlayarak, oldukça ciddi ekonomik ve insani bedeller ödenmesinin önüne geçebilirler.

Çocukların her türden kötü muamele karşısında korumanın toplumsal yolu olan kamusal hizmetler, çocuğa kötü muamelenin önlenmesi, saptanması ve müdahalesini mümkün kılan kaynaklardır. Kötü muamele alanında sunulan kamusal hizmetlerin takibinde ise sivil toplum kuruluşlarının katkıları değerlidir. Sivil toplum kuruluşlarının (STK) çocuğa kötü muameleyi saptamakla ve müdahaleden sorumlu meslek gruplarına destekleri ve özellikle hukuki süreci izlemede aktif rol aldıkları görülmektedir. Gerçekleşen hak ihlalleri karşısında harekete geçen STK'lar hukuki temsilcileri ile müdahalede bulunabilir ve çocuğa kötü muamele içerikli davaları izleyerek müdahil olabilirler. Bu süreçte STK temsilcileri uluslararası insan haklarına uygun ölçütleri temel alırlar, ancak bazı özel durumlarda yükümlülük barındırmayan hukuki kuralları ve bilimsel çalışmaları da göz önünde bulundurmaları gerekebilir. Davayı izleyen sivil toplum örgütleri, işleyişte ortaya çıkan sorunların yargı sisteminden mi yoksa uygulamadan mı kaynaklandığını tespit etmek amacını gözetir. Hukuki sürecin takibi sayesinde ortaya çıkan hak ihlallerinin tekrarlanıp tekrarlanmadığı, gerekli değişikliklerin yapılıp yapılmadığı da saptanır (Egbatan, 2015). Çocuğun mağdur olduğu adli ve hukuki sürecin baştan sona izlenmesi ve sürekli biçimde raporlanması sayesinde, çocuğa kötü muamelenin tekrarı önlenerek çocuk toplum nezdinde korunabilir.

Ülkemizi uluslararası platformda temsil eden Anne Çocuk Eğitim Vakfı (AÇEV), Development Analytics kurumu ile birlikte görece yakın bir süre önce çocuk gelişimi ve eğitimi üzerine bir rapor yayınlaşmıştır (Development Analytics, 2017). Araştırma raporunda; ülkemizde çocuğa yönelik duygusal ve fiziksel şiddet hususunda ailelerin yaygın tutumunun tedirginlik verici olduğu belirtilmektedir. Ayrıca bu raporda, ülkemizde 0-6 yaş çocukların sağlığını sürekli takip eden bir kamusal sistemin eksikliğine, okulöncesi eğitimde okullaşma oranının $\mathrm{AB}$ ve $\mathrm{OECD}$ ülkeleri ortalamalarının çok altında ve öğrenci/öğretmen oranının ise yüksek olması durumlarına işaret edilir. Kamusal sistemde ve kamu personelinde belirtilen yetersizliklerin; çocukların ihmal veya istismarı durumunun fark edilme ve müdahale şansına erişme ihtimallerini düşüren birer etmen olduğu belirtilerek, aile içindeki şiddet vakalarına yönelik verilerin takibi için güvenli bir ortamda toplanması ve toplum ile paylaşımı önerilir (Development Analytics, 2017).

Kamu hizmeti vermekle yükümlü kişi ve kurumların çocukların sağlıklı gelişimi engelleyebilecek, iyi olma hallerini bozabilecek durumlar karşısında ülkemizde yürüttükleri faaliyetler, Çocuk Koruma Haritası'ndan (ÇKH) izlenebilmektedir. Yanı sıra oluşturulan Çocuk Destek Merkezlerinde (ÇDM) şiddet mağduru olan veya suça karışan çocuklara psiko-sosyal destek sunulmaktadır. Avrupa Birliğinin finansmanlığında UNICEF'in teknik desteği ile Türkiye`de Çocuklar İçin Adalet Projesi kaynakları ile oluşturulan ve 2015 senesi itibari ile ÇDMlerinde yürütülmeye başlanan Anka Çocuk Destek Programı ise cinsel istismar da dâhil kötü muamele görme risk altındaki tüm çocuklara sağlanan tek ulusal destek programı olarak dikkat çekmektedir. Anka Cocuk Destek Programı projesi, hem çocuğu hem de aileyi merkeze alan bir 
yaklaşımı benimsemektedir (T.C. Aile, Çalışma ve Sosyal Hizmetler Bakanlığı, t.b.). Etkin bir kamusal hizmet için; önleme, fark etme, bildirme, müdahale etme, iyileştirme- planlama ve faaliyetlerin etkililiği izleme basamakları takip edilir. Çocuk Koruma Kanunu (ÇKK) ülkemizdeki kurumların çocukları kötü muamele karşısında koruma yükümlülüklerini belirten (Çocuk Koruma Kanunu, 2005) en güncel kanundur. ÇKK doğrultusunda görevlendirilen kurumların, kamusal hizmet basamaklarının çoğunu etkin biçimde yerine getirdiği; fakat kişi ve kurumlar arası koordinasyon ile faaliyetlerin etkililiğini izleme basamaklarında eksiklikleri olduğu tespit edilmiştir (Çocuk Koruma Haritası, t.b.). Oysaki, çocuğa kötü muamelenin yaygınlığını, kötü muameleye yol açan ve onu durduran etkenlerin ve müdahalede uygun hizmetin belirlenebilmesi için veri temelli izleme yaklaşımın uygulanması önemli bir unsurdur (Alvarez vd., 2016; Cluver vd., 2020; Development Analytics, 2017; Hubel vd., 2018; Oppenheim-Weller ve Zeira, 2018). Lee ve diğerlerinin (2018) A.B.D.nin New York şehrinde çocuk koruma sistemine kayıtlı 1173 aile arasından seçkisiz biçimde seçilen 104 anneyi ev ziyaretleri temelli uygulanan "Sağlıklı Aileler" programın ile ailelerde tekrarlayan kötü muamelenin önlenmesindeki etkililiği sınanmıştır. Anneler bir ön görüşmeye katılmış ve takip eden görüşmeler ise çocuklar birinci, ikinci ve yedinci yaşındayken gerçekleşmiştir. Bulgular çocuklar yedinci yaşına geldiklerinde, evde ziyaret edilen gruptaki annelerin kontrol grubuna kıyasla teyitli fiziksel istismar ve ihmali tekrarlama olasılıklarının iki katı daha az oranda olduğunu göstermiştir. New York şehri çocuk koruma sistemdeki verileri ve sosyal yardım kayıtları takip edilen tüm ailelerde; çalışmaya katılan tüm annelerin çocukları 3 yaşına gelene kadar teyit edilen kötü muamele tekrar oranları düşük seyretmiş ve programa dâhil olan ve olmayan anneler arasında herhangi bir fark gözlenmemiştir. Çocuklar 3 yaşına geldiklerinden itibaren "Sağlıklı Aileler" programına dâhil olmayan annelerde kötü muamelenin tekrarlanma oranında gözlenmeye başlayan artış ve gruplar arasında saptanan farklışmanın, tüm ailelerin özellikle çalışmanın ilk iki yılında sıkı biçimde takibinden kaynaklandığı düşünülmektedir (Lee vd., 2018). Müdahale çalışmalarının ve uygulanan eğitim programlarının etkililiğinin değerlendirilmesi basamağının toplumun desteğini alarak sürdürülebilmesi değerlidir. Kamu kaynaklarının veri temelli yaklaşımın bir gereği olarak verilerin oluşturulması, izlenmesi ve kamuoyuyla paylaşılması hususlarında kullanımı; ülkemizde ihtiyacın saptanması, nitelikli önleme ve müdahale sistemlerinin oluşması ve sürdürülebilirliğini sağlayacaktır.

\section{SONUÇ VE TARTIŞMA}

Çocuk istismar ve ihmalini içeren kötü muamele ciddi bir toplumsal sorundur. Çocuklar yaşadıkları kötü muameleyi adli mercilere bildirmekte zorlanmakta veya hukuki süreci başlatmakta kararsız kalabilmektedir. Bu kararsızlığın temel nedenleri olarak kötü muamele ile ilişkili edimlerin tanımlanmasındaki sıkıntılar ve adli mercilere dair bazı toplumsal çekinceler tespit edilmiştir. Ülkemizde, çocuğa kötü muamelede nitelikli koruma ve destek sistemleri kurmaya ilişkin ulusal kurumların ve uluslararası destekçilerin belirgin çabaları (ör. Anka Çocuk Destek Programı, Çocuk Koruma Kanunu) mevcuttur. Buna karşın sivil toplum kuruluşlarının ve bağımsız araştırmacıların, ülkemizdeki sisteme dair belirledikleri sıkıntılar ve eleştirilerinin ise dikkate alınması, ülkemizin çocuğun yararına üretebileceği toplumsal koşulları daha ileriye götürebilir. Bu tespitler; hizmet sağlayıcıların çocuk gelişimi alanındaki yetkinliğine (Akyol ve Kutlu, 2019), çocuk korumayı üstlenen kurumlar arası koordinasyona (Karataş vd., 2019) ve müdahalenin sonuçlarının izlenebilir (Akyol ve Kutlu, 2019; Çalışkan, 2019; Egbatan, 2015; Ersoy, 2012) ve dolayısıyla sürdürülebilir olmasına (Development Analytics, 2017) dair bazı 
tıkanıklıkların ülkemizdeki varlı̆̆ına ilişkindir. Mevcut çalışma ile çocuğa kötü muameleyle farklı kurumlarda mücadele eden ve önleme ve müdahale alanında çalışan farklı disiplinlerdeki profesyonel hizmet sağlayıcıların yaşayabilecekleri tıkanıklıklar karşısında; bağlantı kurabilecekleri temel unsurları tanıtmak ve çocuğu koruma ve destekleme alanında neler yapılabileceğine dair ortak bir yol gösterebilmek amaçlanmıştır.

Çocuklar kötü muamelenin duygusal ve davranışsal etkilerini hem kısa hem de uzun süreli deneyimleyen bir gelişimsel gruptur. Günümüzde toplumun çocuğu korumak ve gelişebilecek sorunları engellemek için her türlü istismar ve ihmal hakkında bilgilenmesine olan ihtiyaç hiç olmadığ 1 kadar belirgindir. Kötü muamelenin önlenmesine yönelik nitelikli çalışmalar; yüksek aile içi şiddet ve düşük aile işlevselliği (Cluver vd., 2018; Visser vd., 2016) gibi çocuğun kötü muameleye uğrama riskini oluş̧urabilecek ailevi faktörleri azaltmayı (Lee vd., 2018) hedefler. Bu müdahale çalışmaları ev ziyaretleri (Oppenheim-Weller ve Zeira, 2018) ve planlı eğitimleri (Karale vd., 2020) içermekte ve genellikle annelerin katılımı ile yürütülmektedir. Çocuğa kötü muamele riski olan ebeveynlerin katıldığı çalışmalarda ise; ebeveynlerin çocuklarını koruma yöntemlerini öğrenme, ebeveynliğin zorluklarıyla baş edebilme, çocuklara ulaşabilecekleri uygun yaklaşımlar, çocuklara sınırlarını öğretme (Oppenheim-Weller ve Zeira, 2018) ve çocuk istismarı hakkındaki bilgilerini geliştirme (Karale vd., 2020) gibi temelde iyi ebeveynlik ve ebeveynlerin duygusal ihtiyaçlarına dair konular ele alınmaktadır. Kötü muamelenin kuşaklar arası geçişini ebeveynin psikopatolojileri veya anne-çocuk veya baba-çocuk ikilisi üzerinden değil de aile ekolojisinin bir diğer yönü olan eş ilişkilerini üzerinden anlamak ise, çocuğa kötü muamele konusunda daha derin bir kavrayış sağlayabilir.

Erken çocukluk döneminden ergenliğe değin çocuk gruplarıyla artan sayıdaki çalışmada (Akyol ve Kutlu, 2019; Morris vd., 2016; Y1lmaz Irmak vd., 2018), çocuğun kötü muamelenin önlenmesi sürecine doğrudan katılımı hedeflenmektedir. Çocuklarla düzenlenen önleme çalışmalarının sonucunda çocukların davranış problemlerinde azalma, çocukta kötü muameleye farkındalık ve beceri gelişimi (Altafim vd., 2016; Lachman vd., 2020) gibi ölçülebilir bir grup sonuca ulaşılmıştır. Örneğin Altafim ve diğerleri (2016), aralarında Türkiye'nin de bulunduğu pek çok gelişmekte olan ülkede, çocuğa kötü muameleyi önlemek için uygulanan "Yetişkinler ve Çocuklar Birlikte (ACT) Güvenli Çocuklar Yetiştirmek Ebeveynlik Programı" nın etkisini incelemiştir. Haftada 2 saatlik sekiz oturum sonunda programa en az 6 hafta katılan 82 anne ve ve programa katılmayan ama aynı çocuğa bakım-veren 72 yetişkinin özbildirimleri sonucunda; ebeveynlik uygulamaları ve çocuk davranışlarında olumlu gelişmeler gözlemlenmiştir. Buna karşın önleme programlarının yararı konusunda ihtilaf olduğu da söylenebilir. Buna göre; bazı önleme programlarının sadece büyük yaş grupları için etkili olduğu (Lam vd., 2018), herhangi anlamlı bir etkisinin olmadığı (Akyol ve Kutlu, 2019) ve hatta yaşı daha küçük olan çocuklar için bazı olumsuz sonuçları da doğurabileceği (Lachman vd., 2017) ileri sürülmüştür. Ülkemizde çok sınırlı sayıda ve kısa süreli uygulamalara ait kontrollü bilimsel sonuçlar bulunmaktadır (ör. Yılmaz Irmak vd., 2018). Bu nedenler ile ulusal düzeyde planlanacak programın etkililiğini sağlamanın temel bir niteliği olarak, bu türden çabalara başlarken öncelikle çocuk koruma sistemindeki profesyonellerin, çocukların ve ailelerin istismar ve ihmal hakkında mevcut tecrübeleri, bilgi düzeyleri ve ihtiyaçlarının değerlendirilmesi önerilir.

Çocuğa kötü muamelenin toplumsal etkilerinin yoğunluğu; kötü muamelenin toplumsal yaygınlığ kötü muamelenin toplumda ele alınış biçimi ve yol açtığı açık veya örtük sorunlardan kaynaklıdır (Stouthamer-Loeber vd., 2001). Toplumsal yıkıcı etkilerin önüne geçmek içinse, kötü muameleye maruz kalmış çocuklara kapsamlı bir destek sistemi ile yaklașılması önerilir 
(UNICEF, 2012). Kötü muamele gibi çok katmanlı ve karmaşı sorunların nitelikli biçimde ele alınmasında, iki temel üst iradeye ihtiyaç olduğu ortaya konmuştur. Bu iradelerden biri çocuk koruma ile ilgili alanda çalışan ve hukuki düzenlemeyi uygulayan meslek grupları, diğeri ise sivil toplumun temsilcileridir. Toplumda çocuk haklarının ciddi biçimde ele alınması ve adli, sağlık ve sosyal hizmet alanında sahada çalışanların farkındalık ve yetkinliklerine yönelik eğitim hizmetlerinin erişilebilir olması ise profesyonellerin çocuk koruma alanındaki formasyonunu ve yetkinliğini artıracak, böylelikle çocuğun yararına uygulamalara yönelik usul ve esasların tanınırlığı ve uygulanabilirliğini yaygınlaşabilecektir. Çocuğa kötü muameleye müdahalede yer alan meslek elemanlarının hizmet içi veya lisans eğitimi içeriklerinin çocuğa kötü muamelede adli ve toplumsal meseleleri ve çözüm yollarını içerecek biçimde genişletilmesi yönünde hedeflerin belirlenmesi, toplumsal maliyeti olduğu kadar insani/ahlaki maliyeti azaltmak için de bir gerekliliktir. Ülkemizde çocuğa kötü muamele ile ilgili kamu vakalarının istatistikî bilgilerinin derlenmesine ve STK'ların izleme raporlarının kamunun yararına birer veri olarak kullanılmasına ihtiyaç vardır. $\mathrm{Bu}$ verilerin politika yapıcılarca dikkate alınması, çocuğa kötü muameleyle mücadelede yapısal veya uygulamaya dayalı sorunların çözümüne yönelik atılmış veya atılacak adımların çocuğun yararına bir sonuca varmasını sağlayabilir.

Çocuğun sağlıklı gelişim hakkını destekleyen her tür önleme ve müdahale programı kamu tarafından daha çok benimsenmelidir. Kötü muamaleyi kapsamlı bir toplumsal ve mesleki kavrayışla ele almak; onu oluşturan etkenleri saptamak ve önlemek toplumsal zararı ortaya çıkmadan engelleyebilir. Çok katmanlı bir toplumsal art alanı olan kötü muameleye karşı ülkemizde çocuğu güvende tutmak ve nitelikli toplumsal hizmet vermek çabasında olan profesyonellerin ve kurumların birbirini desteklemeye, toplum tarafindan ve sürdürülebilir politikalarla desteklenmesine ihtiyaçları vardır. Önlemede ve müdahalede sahada kamunun düzenlediği eğitim çalışmalarının etkisinin anlaşılması, fonlanması ve daha verimli olması adına görevli profesyonellerin akademisyenler ile işbirliği yaparak bilimsel ölçüm yöntemlerinin uygulaması önerilir. Bu çalışmanın Türkiye'de çocuk koruma ve müdahale sistemini yürütme ve izlemede yer alan; görevli ve gönüllü olan tüm paydaşların ve nihayetinde çocukların güçlenmesine katkı vereceği düşünülmektedir. Ülkemizde kötü muamele gören çocuğa ve ailelere sunulan destek hizmetlerinin yararlarının bağımsız bilimsel çalışmalarda değerlendirilmesi ve verilerin kamuyla paylaşılması hedefleri yakalandığında, çocuğa ulaşan nitelikli hizmet ve toplumsal fayda yayginlabilecektir. 


\section{KAYNAKÇA}

Akyol, C.Ç. ve Kutlu, M. (2019). The effectiveness of sexual psycho-education program for 8th grade students. Inönü University Journal of the Faculty of Education, 20(2), 591-600.

Arata, C.M., Langhinrichsen-Rohling, J., Bowers, D. ve O'Brien, N. (2007). Differential correlates of multi-type maltreatment among urban youth. Child Abuse \& Neglect, 31(4), 393-415.

Altafim, E.R.P., Pedro, M.E.A ve Beatriz, M. (2016). Effectiveness of ACT Raising Safe Kids Parenting Program in a developing country. Children and Youth Services Review, 70, $315-$ 323.

Altobelli, T. (2010). Cyber-abuse - a new worldwide threat to children's rights. Family Court Review, 48 (3), 459- 481.

Alvarez, M., Padilla, S. ve Máiquez, M.L. (2016). Home and group-based implementation of the "Growing Up Happily in the Family" program in at-risk psychosocial contexts.

Psychosocial Intervention, 25(2), 69-78.

Aydın, A., Tekinsav-Sütçü, S. ve Sorias, O. (2010). Ergenlerde sosyal anksiyete belirtilerini azaltmaya yönelik bilişsel-davranışçı bir grup terapisi programının etkililiğinin değerlendirilmesi. Türk Psikiyatri Dergisi, 21(1), 25-36.

Bandelow, B., Charimo Torrente, A., Wedekind, D., Broocks, A., Hajak, G. ve Rüther, E. (2004). Early traumatic life events, parental rearing styles, family history of mental disorders, and birth risk factors in patients with social anxiety disorder. European Archives of Psychiatry and Clinical Neuroscience, 254(6), 397-405.

Bartlett, J. M., Kotake, C., Fauth, R. ve Easterbrooks, M. A. (2017). Intergenerational transmission of child abuse and neglect: Do maltreatment type, perpetrator and substantiation matter? Child Abuse \& Neglect, 63,84-94.

Belsky, J. (1980). Child maltreatment: an ecological integration. American Psychologist, 35(4), 320-35.

Berzenski, S.R. ve Yates, T.M. (2011). Consequences of multiple maltreatment: a personcentered analysis. Child Maltreatment, 16(4), 250-261. DOI: 10.1177/1077559511428353

Birleşmiş Milletler Çocuklara Yardım Fonu (UNICEF) (2012). United Nations Children's fund, measuring and monitoring child protection systems: Proposed core indicators for the East Asia and Pacific Region, Strengthening Child Protection Series No. 1. UNICEF EAPRO, Bangkok. ISBN: 978-974-685-138-1.

Choi, Y., Kim, Y.S., Kim, S.Y. ve Park, I.K. (2013). Is Asian American parenting controlling and harsh? Empirical testing of relationships between Korean American and Western parenting measures. Asian American Journal of Psychology, 4(1), 19-29.

Cicchetti, D. ve Olsen, K. (1990). The developmental psychopathology of child maltreatment. M. Lewis ve S.M. Miller (Edt.) Handbook of Developmental Psychopathology içinde (s. 261-279). Boston, MA: Springer.

Cicchetti, D., Toth, S. L. ve Maughan, A. (2000). An ecological-transactional model of child maltreatment. J. Sameroff, M. Lewis ve S. M. Miller (Edt.), Handbook of developmental psychopathology içinde (s. 689-722). Kluwer Academic Publishers.

Cluver, L., Meinck, F., Yakubovich, A., Doubt, J., Redfern, A., Ward, C., Salah, N., De Stone, S., Petersen, T., Mpimpilashe, P., Romero, R.H., Ncobo, L., Lachman, J., Tsoanyane, S., Shenderovich, Y., Loening, H., Byrne, J., Sherr, L., Kaplan, L ve Gardner, F. (2016). Reducing child abuse amongst adolescents in low- and middle-income countries: a prepost trial in South Africa. BMC Public Health. 16(1) 567 
Cluver, L.D., Meinck, F., Steinert, J.I., Shenderovich, Y., Doubt, J., Romero, R.H., Lombard, C.J., Redfern, A., Ward, C.L., Tsoenyane, S., Nzima, D., Sibanda, N., Wittesaele, C., De Stone, S., Boyes, M.E., Catanho, R., Lachman, J.M., Salah, N., Nocuza, M. ve Gardner, F. (2018). Parenting for Lifelong Health: a pragmatic cluster randomised controlled trial of a non-commercialised parenting programme for adolescents and their families in South Africa. BMJ Global Health, 3(1), e000539.

Cluver, L., Shenderovich, Y., Meinck, F. Berezin, M.N., Doubt, J., Ward, C.L., Parra-Cardona, J., Lombard, C., Lachman, J.M., Wittesaele, C., Wessels, I., Gardner, F. ve Steinert, J.I. (2020). Parenting, mental health and economic pathways to prevention of violence against children in South Africa. Social Science \& Medicine, 262, 113194.

Collin-Vézina, D., Sablonniére-Griffin, M., Palmer, A.M., Milne, L. (2015). A preliminary mapping of individual, relational, and social factors that impede disclosure of childhood sexual abuse. Child Abuse \& Neglect, 43, 123-134.

Conger, R.D., Ge, X., Elder, G.H., Jr, Lorenz, F.O. ve Simons, R.L. (1994). Economic stress, coercive family process and developmental problems of adolescents [Special issue on children and poverty]. Child Development. 65, 541-561.

Covell, K., Howe, R.B. ve McNeil, J.K, (2010) Implementing children's human rights education in schools. Improving Schools, 13(2), 1-16.

Çalışkan, M. (2019). Toplum ve suç araştırmalarında sınırları aşan bir suç: "çevrimiçi çocuk istismarı" ve bu suça karşı alınabilecek önlemler. Dumlupınar Üniversitesi Sosyal Bilimler Dergisi, 61, 122-131.

Çocuk Koruma Haritası (t.b.). Erişim Adresi: www.cocukkorumaharitasi.info Erişim Tarihi: 3.3.2020.

Çocuk Koruma Kanunu (2005). Erişim Adresi: https://www.mevzuat.gov.tr/MevzuatMetin/1.5.5395.pdf Erişim Tarihi: 20.9.2021.

D’Andrea, W., Ford, J., Stolbach, B., Spinazzola, J., ve Van der Kolk, B.A. (2012). Understanding interpersonel trauma in children: Why we need a developmentally appropriate trauma diagnosis. American Journal of Orthopsyciatry 82(2), 187-200.

Development Analytics (2017). Türkiye'de 0-6 yaş arası çocuğun durumu. İstanbul: Anne Çocuk Eğitim Vakfi (AÇEV). Erişim Adresi: https://www.acev.org/directory/turkiyede-06-yas-arasi-cocugun-durumu/ Erişim Tarihi: 12.04.2021.

Dion, J., Matte-Gagne, C., Daigneault, I., Blackburn, M., Hebert, M., McDuff, P., Auclair, J., Veillette, S. ve Perron, M. (2016). A prospective study of the impact of child maltreatment and friend support on psychological distress trajectory: From adolescence to emerging adulthood. Journal of Affective Disorders, 189, 336-343.

Dünya Sağlık Örgütü [WHO] (2002). Facts: Child abuse and neglect. Erişim Adresi: https://www.who.int/violence injury prevention/violence/world_report/factsheets/en/chil dabusefacts.pdf Erişim Tarihi: 12.10.2019.

Egbatan, M. (2015). Hak temelli politik bir eylem biçimi olarak dava izleme. A. Kurtoğlu (Ed.), Hak temelli izleme ve değerlendirme ve toplumsal cinsiyet anaakımlaştırması içinde (s. 129-156). Ankara: Ceid Yayınları.

Ersoy, A.F. (2012). Vatandaşlık eğitiminde ihmal edilen bir alan: Evde ve okulda çocuk haklarının eğitimi. International Online Journal of Educational Sciences, 4(2), 359-376.

Fantuzzo, J., Sutton-Smith, B., Atkins, M., Meyers, R., Stevenson, H., Coolahan, K., Weiss, A. ve Manz, P. (1996). Community-based resilient peer treatment of withdrawn maltreated preschool children. Journal of Consulting and Clinical Psychology, 64(6), 1377-1386. 
Fantuzzo, J,. Manz, P., Atkins, M. ve Meyers, R. (2005). Peer-mediated treatment of socially withdrawn maltreated preschool children: Cultivating natural community resources. Journal of Clinical Child \& Adolescent Psychology, 34(2), 320-325.

Finkelhor, D., Wolak, J. ve Berliner, L. (2001). Police reporting and professional help seeking by child victims of violent crime. Child Maltreatment, 6 (1), 17-30.

Francis, K.J. ve Wolfe, D.A. (2008). Cognitive and emotional differences between abusive and non-abusive fathers. Child Abuse \& Neglect, 32(12), 1127-1137.

Glasser, M., Kolvin, I., Campbell, D., Glasser, A., Leitch, I. ve Farrelly, S. (2001). Cycle of child sexual abuse: Links between being a victim and becoming a perpetrator. The British Journal of Psychiatry, 179, 482-494. DOI: 10.1192/bjp.179.6.482

Goodman, G. S., Goldfarb, D., Quas, J. A., Narr, R. K., Milojevich, H. ve Cordon, I. M. (2016). Memory development, emotion regulation, and trauma-related psychopathology. D. Cicchetti (Ed), Developmental psychopathology içinde (s. 555-590). New York, NY: Wiley.

Green, B.L., Ayoub, C., Bartlett, J.D., Furrer, C., Chazan-Cohen, R., Buttitta, K., Von Ende, A., Koepp, A. ve Regalbuto E. (2020). Pathways to prevention: Early Head Start outcomes in the first three years lead to long-term reductions in child maltreatment. Children and Youth Services Review, 118, 105403.

Hébert, M., Langevin, R. ve Oussaïd, E. (2018). Cumulative childhood trauma, emotion regulation, dissociation, and behavior problems in school-aged sexual abuse victims. Journal of Affective Disorders, 225, 306-312.

Hubel, G.S., Rostad, W.L., Self-Brown, S. ve Moreland A.D. (2018). Service needs of adolescent parents in child welfare: Is an evidence based, structured, in-home behavioral parent training protocol effective? Child Abuse \& Neglect, 79, 203-212.

Karale, R.B., Malgi, P., Mohite, V.R. ve Choudhari, S.K. (2020). Effectiveness of planned teaching programme on knowledge regarding child abuse among mothers. Indian Journal of Public Health Research \& Development, 11(3), 743-747.

Karataş, K., Aslan, H. ve Kılıç, A. (2019). Türkiye'de çocuk polisinin yapılanması ve görevleri çerçevesinde sosyal hizmetin yeri ve önemi. Toplum ve Sosyal Hizmet, 30(1), 166-186.

Kopiec, K., Finkelhor, D. ve Wolak, J. (2004). Which juvenile crime victims get mental health treatment? Child Abuse \& Neglect, 28, 45-59.

Kuo, J. R., Goldin, P.R., Werner, K., Heimberg, R.G. ve Gross, J.J. (2011). Childhood trauma and current psychological functioning in adults with anxiety disorder. Journal of Anxiety Disorder, 25(4), 467-473. doi:10.1016/j.janxdis.2010.11.011.

Kwak, Y., Mihalec-Adkins, B., Mishra, A. A. ve Christ, S. L. (2018). Differential impacts of participation in organized activities and maltreatment types on adolescent academic and socioemotional development. Child Abuse \& Neglect, 78, 107-117.

Lachman, J.M., Cluver, L., Ward, C.L., Hutchings, J., Mlotshwa, S., Wessels, I. ve Gardner, F. (2017). Randomized controlled trial of a parenting program to reduce the risk of child maltreatment in South Africa. Child Abuse \& Neglect, 72, 338-351.

Lachman, J., Wamoyi, J., Spreckelsen, T., Wight, D., Maganga, J. ve Gardner, F. (2020). Combining parenting and economic strengthening programmes to reduce violence against children: a cluster randomised controlled trial with predominantly male caregivers in rural Tanzania. BMJ Global Health, 5(7), e002349. 
Lam, S., Zwart, C., Chahal, I., Lane, D. ve Cummings, H. (2018). Preventing violence against children in schools: Contributions from the Be Safe program in Sri Lanka. Child Abuse \& Neglect, 76, 129-137.

Lange, B. C. L., Condon, E. M. ve Gardner, F. (2019). A systematic review of association between the childhood sexual abuse experiences of mother and the abuse status of their children: Protection strategies, intergenerational transmission, and reactions to the abuse of their children. Social Science \& Medicine, 233, 113-137.

Lee, P. ve Chou, F. (2016). A training program for Taiwan nurses to improve child abuse reporting. Journal of Clinical Nursing, 26 (15-16), 2297-2306.

Lee, E., Kirkland, K., Miranda-Julian, C. ve Greene, R. (2018). Reducing maltreatment recurrence through home visitation: A promising intervention for child welfare involved families. Child Abuse \& Neglect, 86, 55-66.

Lewis, M. ve Feiring, C. (1992). Indirect and direct effects and family interaction. S. Feinman (Ed.) Social Referencing and the Social Consruction of Reality in Infancy içinde (s. 297321). Boston, MA, Springer. ISBN(online): 978-1-4899-2462-9

Maguire-Jack, K., Gromoske, A. N. ve Berger, L. M. (2012). Spanking and child development during the first 5 years of life. Child Development, 83 (6), 1960- 1977.

Margolin, G. ve Gordis, E. B. (2004). Children's exposure to violence in the family and community. Current Directions in Psychological Science, 13(4), 152-155.

MacKenzie, M. J., Kotch, J. B. ve Lee, L. C. (2011). Toward a cumulative ecological risk model for the etiology of child maltreatment. Children and Youth Services Review, 33(9), 16381647.

Morris, M.C., Kouros, C.D., Janecek, K., Freeman, R., Mielock, A. ve Garber J. (2016). Community-level moderators of a school-based childhood sexual assault prevention program. Child Abuse \& Neglect, 63, 295-306.

Nedim-Bal, P. ve Öner, M. (2014). Sosyal kaygı ile başa çıkma psiko eğitim programının ortaokul öğrencileri üzerindeki etkisi. Ĕgitim Bilimleri Araştırma Dergisi, 4(1), 335-348.

Oppenheim-Weller, S. ve Zeira A. (2018). SafeCare in Israel: The challenges of implementing an evidence-based program. Children and Youth Services Review, 85, 187-193.

Öztürk, A. (2017). Çocuk hakları ve eğitimine psikolojik bir bakış. Uludă̆ Üniversitesi FenEdebiyat Fakültesi Sosyal Bilimler Dergisi, 18(33), 429-451.

Öztürk, A. (2018). Yaşam boyu aile döngüleri ve uyum. M. Akyıldız (Ed.) Aile İçi Uyumlu Etkileşim içinde (s.115-139 ). Eskişehir: Anadolu Üniversitesi Açıöŏgretim Fakültesi Yayınları. ISBN: 978-975-06-2882-5.

Öztürk, A. (2020). Çocuğa kötü muamele: İstismar ve ihmalin önlenebilir psikolojik ve gelişimsel etkileri. Çocuk ve Gençlik Ruh Să̆lı̆̆l Dergisi, 27(1), 7-19.

Pears, K. C. ve Capaldi, D. M. (2001). Intergenerational transmission of abuse: a twogenerational prospective study of an at-risk sample. Child Abuse \& Neglect, 25, 14391461.

Reading, R., Bissell, S., Goldhagen, J., Harwin, J., Masson, J., Moynihan, S., Parton, N., Santos Pais, M., Thoburn, J. ve Webb, E. (2009). Promotion of children's rights and prevention of child maltreatment, The Lancet, 373(9660), 332-343.

Rothenberg, W.A., Hussong, A.M. ve Chassin, L. (2016). Intergenerational continuity in high conflict family environments. Developmental Psychopathology, 28(1), 293-308.

Rubin, K.H., Coplan, R.J. ve Bowker, J.C. (2009). Social withdrawal in childhood. Annual Review of Psychology, 60, 141-171. doi:10.1146/annurev.psych.60.110707.163642 
Sertelin Mercan, Ç. ve Yavuzer, H. (2017). Bilişsel-davranışçı yaklaşımla bütünleştirilmiş sosyal beceri eğitiminin ergenlerin sosyal kayg1 düzeyine etkisi. Elektronik Sosyal Bilimler Dergisi, 16(63), 1187-1202.

Shenderovich, Y., Cluver, L., Eisner, M. ve Murray, A.L. (2020). Moderators of treatment effects in a child maltreatment prevention programme in South Africa. Child Abuse \& Neglect,106, 104519.

Simon, N.M., Herlands, N.N., Marks, E.H., Mancini, C., Letamendi, A., Li, Z., Pollack, M.H., Van Ameringen, M. ve Stein, M.B. (2009). Childhood maltreatment linked to greater symptom severity and poorer quality of life and function in social anxiety disorder. Depression and Anxiety, 26, 1027-1032.

Sofuoğlu, Z., Sarıyer, G. ve Ataman, M.G. (2016). Child maltreatment in Turkey: Comparison of parent and child reports. Central European Journal of Public Health, 24(3), 217-222.

Stoltenborgh, M., Bakermans-Kranenburg, M.J., Lenneke, R.A.A. ve van Ijzendoorn, M.H. (2012). The universality of childhood emotional abuse: a meta-analysis of worldwide prevalence. Journal of Aggression, Maltreatment \& Trauma, 21(8), 870-890. DOI: 10.1080/10926771.2012.708014

Stouthamer-Loeber, M., Loeber, R., Homish, D.L. ve Wei, E. (2001). Maltreatment of boys and the development of disruptive and delinquent behavior. Development and Psychopathology, 13, 941-955.

Taal, M. ve Edelaar, M. (1997). Positive and negative effects of a child sexual abuse prevention program. Child Abuse \& Neglect, 21(4), 399-410. DOI: 10.1016/S0145-2134(96)00179-2

Tat, M. ve Öztürk, A. (2019). Çocuk cinsel istismarında kendini açığa vurma sürecine ekolojik sistem modeli yaklaşımı. Psikiyatride Güncel Yaklaşımlar, 11(3), 363-385.

T.C. Aile, Çalışma ve Sosyal Hizmetler Bakanlığı (t.b.). Anka çocuk destek programı. Erişim Adresi: https://www.aile.gov.tr/chgm/sayfalar/anka-cocuk-destek-programi/ Erişim Tarihi: 13.9.2021.

T. C. Kalkınma Bakanlığı (2014). Onuncu kalkınma planı 2014-2018 çocuk çalışma grubu raporu. Erişim Adresi: http://www.kalkinma.gov.tr/Lists/zel\%20htisas\%20Komisyonu\%20Raporlar/Attachments/ 244/\%C3\%A7ocuk\%20\%C3\%A7al\%C4\%B1\%C5\%9Fma\%20grubu\%20OIKI.pdf.

Erişim Tarihi: 13.12.2016.

T.C. Milli Eğitim Bakanlığı [MEB] (2019, 12 Aralık). Özel eğitim ve rehberlik genel müdürlüğü rehberlik programları. Erişim Adresi: https://orgm.meb.gov.tr/www/rehberlikprogramlari/icerik/102. Erişim Tarihi: 02.04.2021.

Teng, Y.T., Kuo, L.T. ve Zhou, Q. (2018). Maternal employment and family socioeconomic status: Unique relations to maternal stress, parenting beliefs, and preschoolers' adjustment in Taiwanese families. Journal of Child and Family Studies, 27(11), 3506-3519.

Thomas, R. ve Zimmer-Gembeck, M. J. (2012). Parent-child interaction therapy: An evidencebased treatment for child maltreatment. Child Maltreatment, 17(3), 253-266.

Tracy, M., Salo, M ve Appleton A. A. (2018). The mitigating effects of maternal support and paternal involvement on the intergenerational transmission of violence. Child Abuse \& Neglect, 78, 46-59.

Turner, C.W., Robbins, M.S., Rowlands, S. ve Weaver, L.R. (2017). Summary of comparison between FFT-CW and Usual Care sample from Administration for Children's Services. Child Abuse \& Neglect, 69, 85-95. 
Türkiye İstatistik Kurumu [TÜIK] (2020, Temmuz). Güvenlik birimine gelen veya getirilen çocuk istatistikleri, 2015-2019. Türkiye İstatistik Kurumu Haber Bülteni, 33632. Erişim adresi: https://data.tuik.gov.tr/Bulten/Index?p=Juvenile-Statistics-Received-Into-SecurityUnit-2015-2019-33632.

Visser, M., Schoemaker, K., de Schipper, C., Lamers-Winkelman, F. ve Finkenauer, C. (2016). Interparental violence and the mediating role of parental availability in children's trauma related symptoms. Journal of Child \& Adolescent Trauma, 9(2), 115-125.

Yates, T. M. (2007). The developmental consequences of child emotional abuse: A neurodevelopmental perspective. Journal of Emotional Abuse, 7, 9-34. DOI: $10.1300 / \mathrm{J} 135 \mathrm{v} 07 \mathrm{n} 02$

Yılmaz Irmak, T., Kızıltepe, I., Aksel, Ş., Güngör, D. ve Eslek, D. (2018). Mika ile kendimi korumayı öğreniyorum: Cinsel istismarı önleme programının etkililiği. Türk Psikoloji Dergisi, 33(81), 41-57.

Yıldırım, N. ve Kublay, G. (2016). 1-4 Yaş çocuklarına yönelik ev kazalarını önleme programının etkinliği. Hacettepe Üniversitesi Hemşirelik Fakültesi Dergisi, 3(2), 1-13.

Young, J.C. ve Widom, C.S. (2014). Long-term effects of child abuse and neglect on emotion processing in adulthood. Child Abuse \& Neglect, 38(8), 1369-1381. 